\title{
The effect of tillage depth and traffic management on soil properties and root development during two growth stages of winter wheat (Triticum aestivum L.)
}

\author{
David Hobson ${ }^{\text {a }}$, Mary Harty ${ }^{\mathrm{a}}$, Saoirse R. Tracy ${ }^{\mathrm{a}}$, Kevin McDonnella, b \\ a School of Agriculture and Food science, UCD, Belfield, Dublin 4, Ireland \\ ${ }^{\mathbf{b}}$ Biosystems Engineering Ltd, NovaUCD, Belfield, Dublin 4, Ireland \\ Correspondence to: David Hobson (david.hobson@ucdconnect.ie).
}

Abstract

The management of agricultural soils during crop establishment can affect root development by changes to soil structure. This paper assesses the influence of tillage depth $(250 \mathrm{~mm}, 100 \mathrm{~mm} \&$ zero $)$ and traffic management (conventional tyre pressure, low tyre pressure \& no traffic) on wheat root system architecture during winter wheat (Triticum aestivum L.) tillering and flowering growth stages (GS) on a long-term tillage trial site. The study revealed that zero-tillage systems increased crop yield through significantly greater root biomass, root length density and deeper seminal rooting analysed using X-ray Computed Tomography (CT). In general, conventional pressure trafficking had a significant negative influence on crop yield, root development, bulk density and total soil porosity of deep and shallow tillage conventional pressure systems compared no traffic zero and deep tillage systems. Visual improvements in soil structure under zero tillage may have improved crop rooting in zero tillage treatments through vertical pore fissures (biopores), enhancing water uptake during the crop flowering period. This study highlights the implications of soil structural damage on root system architecture created by compaction in crop production. The constricted root systems found in conventional pressure shallow tillage, zero and deep tillage trafficked regimes emphasizes the importance of using technology to improve soil management and reduce the trafficked areas of agricultural fields.

\section{Introduction}

Soil resources are under significant pressure from anthropogenic activities especially conventional tillage. The resulting soil degradation has significant implications for food security globally (Lal, 2010). Changing weather patterns from prolonged rain to drought periods are being experienced on a global scale, substantiating the challenges faced by food producers. In 2018, worldwide wheat production fell by 34.5 million ton due to prolonged droughts across Europe, Australia, and Canada. Soil compaction from field traffic is a well-recognized problem in many parts of the world (Chan et al., 2006; Arvidsson and Keller, 2007; Naderi-Boldaji et al., 2018 ) affecting 33 million hectares in Europe alone (Akker and Canarache, 2001). Soil compaction is a form of physical degradation caused by short crop rotations and heavy farm machinery working on low organic matter soils in wet conditions resulting in the loss of pore space due to an externally applied load, forcing soil aggregates together 
(Defossez and Richard, 2002). The resulting anaerobic high density soils have significantly reduced capacity to store water and nutrients required by growing crops (Hamza and Anderson, 2005) and severely compacted soils prevent soil exploration from root growth (Tracy et al., 2012).

Soil compaction is due in part to the pressure to complete field operations such as harvesting or drilling often in short windows of good weather, which is exacerbated by the increasing use of larger machinery with increasing axle loads designed to improve operational efficiencies. Common agricultural operations are conducted using wheeled farm machinery which has tripled in weight and power since 1966 with wheel loads rising by a factor of six (Chamen, 2006). When soils are cultivated in moist or wet conditions, soils can not withstand the compressive forces applied post cultivation by heavy farm machinery traffic during operations such as seeding (Raper, 2005), resulting in soil degradation (Batey, 2009). When soil is wet, tyre stress can propagate a greater distance down through the soil profile. The depth and severity of soil stress is related to soil moisture, traction device applied (track or tyre), track size, tyre inflation pressure and wheel load (Naderi-Boldaji et al., 2018).

Reforming the approach to soil management to mitigate challenges such as soil compaction and soil erosion offer significant financial and environmental benefits compared to conventional agriculture. Cultivation practice using minimal, or zero tillage techniques are widespread across many climatic conditions from semi-arid Canadian plains to the temperate climates of Western Europe. In conventional tillage, the soil is either inverted $>200 \mathrm{~mm}$ using a mouldboard plough or deeply ripped using tines. The soil is then cultivated again to break down soil aggregates to a crumb structure or fine tilth that is suitable to plant seeds (Morris et al., 2010). Conservation tillage, also known as non-inversion tillage or reduced tillage, has been used for decades to improve soil structure and health (Skaalsveen, Ingram and Clarke, 2019). Under conservation tillage, soil is disturbed to a lesser extent ( $<100 \mathrm{~mm}$ using tines or discs) or not disturbed at all such as under zero tillage which involves the direct placement of seed into undisturbed crop residues ( Soane et al., 2012).

The successful adaption of reduced tillage systems is not universally guaranteed with factors such as soil texture and drainage, crop type and weather influencing successful implementation (Soane et al., 2012). In northern Europe, crop yields under reduced cultivation systems rarely exceed those achieved by ploughing (Arvidsson, 2010). The exception under drier arid climates such as Spain, no tillage improved crop yields by moisture retention in below average rainfall years ( Muñoz-Romero et al., 2010). Higher bulk density and penetration resistance are typically found throughout the formerly tilled or "plough pan" layer in no tillage soils within the first two years of adoption, resulting in root mechanical impedance (V. Boguzas et al., 2006). Yet, over time, long term zero tillage has shown to attribute improvements in soil pore architecture and continuity throughout the soil profile by bioturbation, suggesting roots could penetrate to lower soil horizons ( Cooper et al., 2021).

To date, studies have focused on how tillage influences physical soil properties (bulk density, cone penetrometer, soil aeration) with root and crop yield responses (Whalley et al., 2008; Pires et al., 2017; Czyż, 2004). Soil types and tillage systems have a considerable influence on the structural integrity of soil which controls rooting potential (Morris et al., 2017). Studies have shown that low pressure tyres can reduce surface compaction compared to high tyre pressure (Soane et al., 1980; Boguzas and Hakansson, 2001). As trafficking increases soil strength and reduces a plant root's ability to penetrate soil layers, it is important to understand the relationship between tillage depth and root system architecture during the growing season in response to trafficking. A dearth of information 
exists on how tillage depth and tyre pressure affect rooting properties and crop yield on longer term field sites. Yield reduction by soil surface compaction can increase abiotic stress in plants in three ways. It reduces soil aeration, increases mechanical impedance of roots which in turn reduces root exploration of soil thus, mitigating the extraction of water and nutrients from the soil resource (Chamen, 2011).

Quantitative measurement of root system architecture in three dimensions (3D) has become tractable using X-ray CT in pot experiments (Mairhofer et al., 2017). Few examples of root studies using high resolution X-ray computed tomography have been successfully conducted in field trials using undisturbed soil cores. Many studies have focused on measuring soil structural properties such as porosity, soil pore size and distribution and the influence of tillage method and trafficking (Millington et al., 2017; Rab et al., 2014). However, studying root development and architecture in three-dimensional field structured soils remains challenging with X-ray CT due to a bottleneck of rapid and standardized root extraction methods available, insufficient resolution and inability to segment similarities in grey scale values between root and organic materials (Zhou et al., 2021; Mooney et al., 2012; Pfeifer et al., 2015).

The purpose of this paper was to identify the in-situ relationships between tillage depth and crop establishment method on root architecture and crop yield under different traffic methods during two key growth stages of winter wheat. X-ray CT was deployed to show if root architecture behaviors could be captured in-situ to the soil structural environment created by the tillage method. Three cultivation practices and traffic management systems were studied: Deep tillage $(250 \mathrm{~mm})$, shallow tillage $(100 \mathrm{~mm})$ and zero tillage, under no traffic, low tyre pressure and conventional tyre pressure. The objectives of this study were to (i) assess the relationship between of traffic management and three tillage depths and its effects on root system architecture and soil physical properties (ii) Utilise 3D image analysis along with 2D destructive methods to verify rooting properties responsible for crop yield.

\section{Materials and Methods}

\subsection{Site and soils}

The study took place during the 2018/19 growing season. The experimental site is 3.12 ha, located at Harper Adams University (HAU), Edgmond, Newport, England (52.779738 N, -2.426886 W). The HAU site is a loamy sand soil consisting of the Olerton and Salwick series soils (Eutric Endogleyic Arenosol and Chromic Endostagnic Luvisol respectively) (Millington et al., 2017). Further details of the soil properties are described in Table 1. To highlight if any site variability existed across the site, soil properties were examined for fertility ( $\mathrm{pH}$ and nutrient levels), bulk density, soil strength and soil moisture. Particle size analysis (Gee and Or, 2002) was conducted to determine soil texture classifications. The trial site was established in 2011 for previous studies with plots and treatments carried out in the same location.

In the year prior to this study, it was necessary to plant a break crop (2017/18) as part of a standard crop rotation to improve soil conditions and reduce diseases such as take all (Gaeumannomyces graminis var. tritici). A field bean (Vicia Fabia) break crop was planted, and yields were assessed to ensure the trial site was uniform with no underlying issues. Since the trial site began, the crop rotation has been first winter wheat (Triticum aestivum $L$.) 
111 harvest in 2012 followed winter wheat in 2013, winter barley (Hordeum vulgare L.) 2014, winter barley 2015,

112 followed by a cover crop "TerraLife-N-Fixx" (DSV United Kingdom Ltd, 2015); Spring oats 2016, spring wheat

1132017 and winter beans 2018. For this trial, winter wheat (Triticum. aestivum L. cv. Graham) was drilled early

114 October 2018 when the soil was dry, friable and soil temperatures $>6{ }^{\circ} \mathrm{C}$. The seeding rate was 250 seeds per $\mathrm{m}^{2}$

115 and drilling took place on the $5^{\text {th }}$ of October. This is in line with local normal farming practice.

Table 1. Description of the topsoil $(0-300 \mathrm{~mm})$ properties for Harper Adams University trial site, Shropshire, UK.

\begin{tabular}{|c|c|c|}
\hline Property & Units & \\
\hline \multirow[t]{2}{*}{ Location } & Latitude & $52.779738 \mathrm{~N}$ \\
\hline & Longitude & $-2.426886 \mathrm{~W}$ \\
\hline \multirow[t]{3}{*}{ Soil type } & Landis group* & Argillic brown earths, brown sands \\
\hline & Landis series* & Salwick, Ollerton \\
\hline & FAO & Luvisol \& Arenosol \\
\hline Sand $(2000-65 \mu \mathrm{m})$ & $\mathrm{g} \mathrm{g}^{-1}$ dry soil & 0.743 \\
\hline Silt $(63-2 \mu \mathrm{m})$ & $\mathrm{g} \mathrm{g}^{-1}$ dry soil & 0.115 \\
\hline Clay $(<2 \mu \mathrm{m})$ & $\mathrm{g} \mathrm{g}^{-1}$ dry soil & 0.143 \\
\hline Texture & SSEW class & Loamy sand \\
\hline Organic matter (LOI) & $\mathrm{g} \mathrm{g}^{-1}$ dry soil & 0.044 \\
\hline
\end{tabular}

*Landis Soil guide (Cranfield University, 2021).

The experiment was a randomised $3 \times 3$ factorial arrangement of 9 treatments in four complete replicate blocks. Each plot was $4 \mathrm{~m}$ wide $\mathrm{x} 84 \mathrm{~m}$ long with exception of block 4 . Block 4 is $78.2 \mathrm{~m}$ long for operational reasons. Tramlines were at a $90^{\circ}$ angle to plots with $24 \mathrm{~m}$ spacing for fertilising and spraying operations throughout the growing season. A split-plot design was used, half the plot $(30 \mathrm{~m})$ designated for sampling and the other half was undisturbed for yield data collection. The half plot for sampling was sub-divided for the two sampling stages, ensuring sampling did not occur near the same location as the previous sample. Cultivation for spring beans in 2017 was performed at three depths, $250 \mathrm{~mm}$ for deep tillage, $100 \mathrm{~mm}$ for shallow tillage and direct into stubble for zero tillage. In the winter wheat trial, soil cores were collected at tillering (Growth stage (GS) 25) and the flowering stage (GS 61-69) (Zadoks, Chang and Konzak, 1974) in July 2019. tillage treatments are denoted as: Treatment $1=$ Deep tine cultivator at $250 \mathrm{~mm}$ (DT) for deep tillage similar to (Ren et al., 2019), treatment 2 = shallow disc cultivation at $100 \mathrm{~mm}$ (ST) and treatment $3=$ zero tillage using a direct seed drill (ZT). In combination with the different tillage depths, three traffic regimes were used in this study 
no traffic (NT), conventional tyre pressure (CP) and low tyre pressure (LP). Tillage depths were combined with traffic management practices for the 9 treatments (DTNT, DTCP, DTLP, STNT, STCP, STLP, ZTNT, ZTCP \& ZTLP).

\subsubsection{Tillage equipment and tyres}

Primary cultivations in HAU involved a rigid tine and conical disc cultivator (Vaderstad Topdown) at $250 \mathrm{~mm}$ depth to cut surface residues, loosen, mix, and consolidate the seedbed. The same implement was used for shallow tillage treatments with tines adjusted upwards to reduce tillage depth $(100 \mathrm{~mm})$. A $290 \mathrm{hp} \mathrm{Massey} \mathrm{Fergusson} 8480$ with a track width of $2.1 \mathrm{~m}$ was used. Increased flexion AxioBib tyres were fitted IF 650/85 R38 179D TL on the rear axle and (IF 600/70 R30 159D TL) at the front. A pneumatic disc seed drill (Vaderstad Spirit) was used to sow the crop with $167 \mathrm{~mm}$ row spacing. The same drill was used to sow the zero tillage plots with the tines and discs lifted to minimise disturbance (Kaczorowska-Dolowy et al., 2019).

For the tyre pressure treatment, the conventional tyre treatments were inflated to 1 bar for front and rear tyres during cultivations. Low tyre pressure treatments and controlled traffic farming (CTF) plots operated on 0.7 bar front and 0.8 bar on the rear axle. A front weight block of $540 \mathrm{~kg}$ was applied to the tractor for tillage primary cultivation. All operations were performed under the same wheel-ways to keep traffic free zones for CTF plots. During harvest, a Claas Dominator combine operated on a 4-m header, matching plot sizes (Smith, 2016). Crop husbandry was carried out in accordance to the AHDB guidelines and soil fertility test analysis (AHDB, 2018).

\subsubsection{Soil physical properties}

Soil bulk density samples were also collected within the trafficked and non-trafficked area of the plot, to represent the bulk density of the tillage treatments. Samples were replicated three times. Each core sample was $50 \mathrm{~mm}$ in width and 300mm in length. An Eijkelkamp® soil corer was used to take bulk densities samples. Each bulk density sample was taken within $0.5 \mathrm{~m}$ of the location of the soil cores taken for X-ray CT. The objective was to represent the physical constraints (or lack of) for root growth in each plot examined. The method used in this study involved splitting the bulk density sample into three $100 \mathrm{~mm}$ sections $(0-100 \mathrm{~mm}, 100-200 \mathrm{~mm}$ and $200-300 \mathrm{~mm})$ similar to (Smith, 2016). The corer was opened in the field and split using a knife and ruler.

The core sections were stored in resealable bags and labelled before transporting to the laboratory for analysis. Intact fresh soil cores were weighed prior to drying to record sample fresh weights. Samples were placed into an oven at $105^{\circ} \mathrm{C}$ for $24 \mathrm{~h}$ and reweighed to determine moisture $\%$ as per equation 1 and dry bulk density as per equation 2 (Campbell and Henshall, 2000).

$$
\text { Moisture } \%=\text { fresh weight }(\mathrm{g})-\text { dry weight }(\mathrm{g}) / \text { dry weight }(\mathrm{g}) * 100 \quad \text { Equation } 1
$$


Dry bulk density $\left(\mathrm{Mg} \mathrm{m}^{-3}\right)=$ dry soil weight $(\mathrm{Mg}) /$ soil volume $\left(\mathrm{m}^{-3}\right)$

Equation 2.

\subsubsection{Penetration resistance (PR)}

Soil penetration resistance data were collected on each plot (in the wheel-ways and in the centre of the plot) down to $450 \mathrm{~mm}$ with a depth increment of $25 \mathrm{~mm}$ between each recorded penetrometer reading. A cone penetrometer (Data Field, Ukraine) was used, recording soil strength in $\mathrm{kPa}$, the location and depth via built-in GPS device. Only the PR samples were recorded at $450 \mathrm{~mm}$ to complete a reading on the data logger. It is also widely known that roots penetrate past "tillage pans" ( Bengough et al., 2011). Five penetrations were made both under and between the wheel ways on each plot at GS 25 sampling to represent each treatment. PR was measured when soil conditions were at field capacity to ensure accuracy of each reading.

\subsubsection{Soil porosity analysis}

Before soil porosity analysis on ImageJ software (version 1.52) (Schneider et al., 2012) could commence, an image stack was created in VG Studio Max ${ }^{\circledR}$ for each scan. The contrast was adjusted to improve the uniformity and visibility of the soil pores. The register object tool corrected scan discrepancies for soil core angle. Straightening the scan allowed a cylindrical shape to be cropped and the tube edges and air space outside of the soil core removed. This enabled soil data to be captured throughout the soil core. A new volume was selected and extracted from the original. This created a separate cropped image volume to work from. The surface determination tool in VG Studio Max ${ }^{\circledR}$ was used to threshold pore spaces within the solid matrix. The tool defines the contour of objects, separating 3D data into regions, providing meaningful soil data (Borges de Oliveira et al., 2016). The image was then inverted to remove the extracted variables from the image and highlighting the pore spaces in the soil core. The processed image was exported as an *TIFF image stack for further analysis using Image J software.

Soil pore characteristics were measured using X-ray CT to establish information about the 3D soil environment for root growth without disrupting the structural integrity of the soil core. The original grey-scale X-ray CT images were analysed using ImageJ software. The scale was set for each dataset to define to spatial scale of the active image. The unit of length was set in millimeters and the known distance was $0.045 \mathrm{~mm}(45 \mu \mathrm{m})$. Each scanned core was cropped to remove the area outside of the soil column. The action of soil coring during sampling had the effect of loosening the bottom $20 \mathrm{~mm}$ of the core, therefore 415 slices at the bottom of each scan were discarded to remove the loosening effect due to the sampling process. The downward movement of the PVC pipe also caused a smearing effect on the soil at the outside edge of the core and this area was also removed by cropping.

The processed image was 1220 x 1220 pixels in size. Applying the contrast enhancement filter helped normalize all slices. The filter reduces the differences in pixel grey-level between slices known as beam hardening (Wildenschild et al., 2002). The ImageJ Huang automatic threshold algorithms were used for each scan to create binarized images and separate the air-filled pores from the background region. The binarized scans were despeckled twice to remove unwanted noise within each scanned image, improving analysis and accuracy of the 
investigated pores. The Look Up Table (LUT) was inverted to change the white pores to black, ensuring analysis calculated the air-filled pores and not the soil matrix. The resulting binary images were analysed using the Analyze Particles tool which provided information for average pore size, total area and percentage porosity for each individual image.

\subsubsection{Soil core sampling}

Field soil core size was chosen to capture as much root material growing in the field as possible while minimizing the trade-off that exists with the X-ray CT technology between image resolution and core size (Mooney et al., 2012; Zhou et al., 2021). The core dimensions were consistently 70 x $300 \mathrm{~mm}$ (diameter x depth) for each sample. Soil cores were extracted from the field sites at GS 25 in February and again at GS 61 in June. Sampling was carried out at GS 61 during wheat anthesis, when root growth is at its peak (Gregory et al., 1978). Due to high moisture deficits in HAU (43 mm) during sampling at GS 61 in early July, the soil sample area was wetted with $2.5 \mathrm{~L}$ of water and allowed to infiltrate. This lubricated the soil, reduced soil fracturing, and allowed tube insertion and soil core extraction to take place as smoothly as possible. Polyvinyl chloride (PVC) drainage pipes were cut to size $(70 \times 300 \mathrm{~mm})$ and these tubes were used to collect soil cores (as per Millington et al, 2017).

A single wheat plant sample was located at random in each plot. The selected plant was cut at the base of the stem with a scissors and the above ground biomass discarded The PVC tube was placed (plant centred) directly over the remaining plant stubble to maximise root system capture. Tubes were inserted into the soil using a mallet in the crop rows in the centre of the plots between the wheel tracks (not trafficked by wheel) for untrafficked samples for no traffic samples. A second core was taken in the wheel way for the tyre pressure treatments. A small block of timber was used when hammering in the tube to protect tubes and soil cores from damage. A total of 72 samples were extracted on each sampling occasion and examined in this study. The PVC tubes were inserted into the soil to a depth of $300 \mathrm{~mm}$. The soil core was extracted carefully using a spade and the sample locations were backfilled with soil. Following sampling, cores were sealed (top and bottom) using tape, labelled, and carefully placed into boxes protected with bubble wrap. Cores were tightly packed and insulated to minimise movement and drying of samples during transit to the laboratory for analysis. Samples were transferred to refrigerated storage $\left(<4^{\circ} \mathrm{C}\right)$ to prevent and reduce compositional changes to the soil through biological degradation.

\subsubsection{X-ray computed tomography $(C T)$ - Root analysis}

Soil cores were transferred to the University College Dublin (UCD) X-ray CT facility at the Rosemount Experimental Research Station at Belfield Campus, UCD, Ireland. The soil cores were scanned using a Phoenix ${ }^{\circledR}$ v|tome|x M $240 \mathrm{kV}$ scanner (GE Measurement and Control solution, Wunstorf, Germany). The v|tome|x M was 
set at a voltage of $90 \mathrm{kV}$ and current of $400 \mu \mathrm{A}$ to optimize contrast between background soil and root material. A voxel resolution of $45 \mu \mathrm{m}$ was achieved by using the 'Multi Scan option' to scan in 4 segments. A total of 1800 projection images per section were taken at $200 \mathrm{~m} / \mathrm{s}$ per image using the 'Fast Scan option', which has the default values of an image averaging of 1 and 0 skip. No filters were used during scanning. The total scan time per core was 24 minutes or 6 minutes per section. Once scanning was complete, the images were reconstructed using Phoenix datos|x2 rec reconstruction software, the four scans were assembled into one 3D volume for the whole core. Core samples were scanned within a week of the sampling date, the scanned core was $300 \mathrm{~mm}$ in length and $70 \mathrm{~mm}$ diameter. The software corrected movements during the scanning process and removed noise from scanned images.

\subsubsection{X-ray CT root segmentation}

Image analysis for X-ray CT images was performed using the software VGStudioMax ${ }^{\circledR}$, version 3.2 (Volume Graphics GmbH, Heidelberg, Germany) to segment roots and soil porosity. Roots were segmented by setting seed points and using selected threshold values in the "Region grower" that enabled fast and accurate selection of greyscale voxels (3D pixels) pertaining to root materials. The root system was extracted from the greyscale CT image of soil using the VGStudioMax ${ }^{\circledR}$ semi-automated local adaptive thresholding “Region Growing” selection tool, similar to (Tracy et al., 2013). Root volumes were calculated by segmenting the root region of interest (ROI). Once the roots were segmented from the image, erosion and dilation tool was selected at 1 pixel using the Region Growing tool. Root system architecture parameters such as root vertical depth, root volume and root surface area were measured from the segmented root systems. Root vertical depth was calculated on the $\mathrm{Z}$ axis in VGStudioMax ${ }^{\circledR}$ from the length of a complete root from the base seed point.

\subsubsection{Destructive 2 D root analysis}

After the soil cores were scanned, the soil and root material were separated by root washing gently with a water jet hose. Two sets of sieves with a mesh size of $2 \mathrm{~mm}$ and $1 \mathrm{~mm}$ collected root material. Roots were washed and soil material removed before the roots were placed into a sealed and labelled bag filled with water. The washed root samples were placed into a freezer until scanning and analysis with WinRHIZO ${ }^{\mathrm{TM}}$ scanning and software (version 2016a Regent Instruments, Canada) commenced. The root samples were thawed before scanning with the WinRHIZO ${ }^{\mathrm{TM}}$ software. Large root stumps were removed from the sample prior to placing it inside the tray to reduce root misrepresentation (Wang and Zhang, 2009). Roots were placed onto a clear transparent tray (30 $\mathrm{cm} x$ $20 \mathrm{~cm}$ ) with water. A pair of plastic forceps were used to spread out root seminal and lateral roots. Images were scanned at a resolution of $600 \mathrm{dpi}(42 \mu \mathrm{m}$ pixel size) with an Epson Perfection V800 scanning system. Root images were measured for root length, root surface area, average root diameter and root volume for the total soil core. This output was used to verify the 3D root outputs from VGStudioMax ${ }^{\circledR}$ (Flavel et al., 2017; Tracy et al., 2012). The WinRHIZO ${ }^{\mathrm{TM}}$ software enabled rapid assessment of root parameters. It calculated the root volume by determining the average root diameter and root length by pixel counting the $2 \mathrm{D}$ root image and then assuming the root shape was cylindrical. The WinRHIZO ${ }^{\mathrm{TM}}$ used a skeletonization method for characterizing root systems (Himmelbauer, Loiskandl and Kastanek, 2004). The software uses greyscale values in *.TIFF file format. The 
output of the images was distinguished by global thresholding analyses for root diameter while root length was validated by skeleton images. After WinRHIZO ${ }^{\mathrm{TM}}$ scanning, the roots were removed from the scanning tray using forceps. The root samples were dried at $70^{\circ} \mathrm{C}$ for 24 hours and the root biomass samples were weighed.

\subsection{Soil Moisture Deficit Model}

Soil Moisture Deficit (SMD) was calculated based on the SMD hybrid model for Irish grassland (Schulte et al., 2005). Rainfall, wind speed (m/s), sunshine hours, maximum and minimum temperature data were taken from the nearest weather station located in Newport, Shropshire 6km from the site (Met office, 2019).

\subsection{Statistics}

Data from the scanned (destructive and non-destructive) images and root biomass were not normally distributed. Non-normal data do not meet the assumptions underpinning ANOVA (Analysis of Variance); therefore, all data underwent log transformation (in Microsoft Excel) before being exported to Minitab $18^{\circledR}$ where analysis of variance (ANOVA) was performed to homogenize the variances of the compared means (Poorter and Garnier, 1996). For linear regression analysis, residuals of data were made to ensure that the assumptions of the analysis were met (normal distribution, constant variance, etc). Normality was tested using the Anderson-Darling test in Minitab 18®.

\section{Results}

\subsection{Growing conditions during crop season}

In 2018, crops were established at low soil moisture levels, which may have reduced soil compaction caused by tillage operations across all site locations. From January to August (2019), $418.6 \mathrm{~mm}$ of rainfall was recorded at HAU, $68 \mathrm{~mm}$ in total for January and February. Soil moisture deficits reached $66.2 \mathrm{~mm}$ in HAU (Supplementary fig. S1) by early June 2019. High soil moisture deficits were recorded from early April to June, causing drought stress during rapid growth periods (Met office, 2019).

\subsubsection{Soil properties - Bulk density \& Penetrometer resistance}

The calculated probability ( $P$-value) and standard error of the mean (SEM) from one-way ANOVA analysis is given in Fig. 1 for bulk density presented for 0-100 mm, 100-200 mm, and 200-300 mm measurements. In the top 0-100 mm, bulk density was significantly higher in DTCP $\left(1.66 \mathrm{Mg} \mathrm{m}^{-3}\right)$ and STCP $\left(1.44 \mathrm{Mg} \mathrm{m}^{-3}\right)$ treatments compared to ZTNT (0.994 $\left.\mathrm{Mg} \mathrm{m}^{-3}\right)$ and DTNT $\left(0.97 \mathrm{Mg} \mathrm{m}^{-3}\right)(\mathrm{P}<0.01)$. STNT $\left(1.09 \mathrm{Mg} \mathrm{m}^{-3}\right)$ was significantly higher than ZTNT and DTNT and only significantly lower than DTCP. In the middle horizon (100-200 mm), a significant interaction between trafficking treatment was found. Bulk density was significantly lower in DTNT 


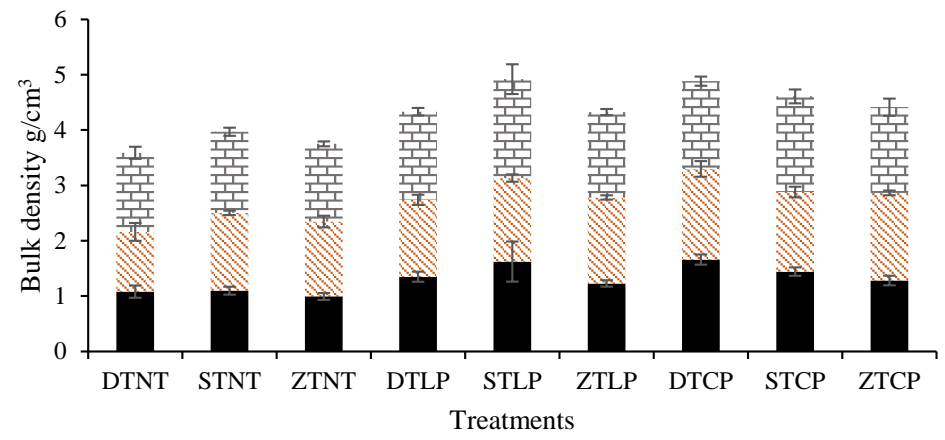

- Bulk density 0-100 MM $\approx$ Bulk density 0-200 MM $\neg$ Bulk density 200-300 MM

319 Figure 1. Soil bulk density $\mathrm{g} / \mathrm{cm}^{3}$ for tillage $\mathrm{x}$ traffic treatments for three depth layers.

Penetration resistance (PR) was recorded in February 2019 when the soil was at field capacity. Measurements were grouped into three groups, 0-150 mm, 150-300 mm, and 300-450 mm depth layers. Figure 2 depicts the combined three layers grouped into one $0-450 \mathrm{~mm}$ graph. The ANOVA analysis revealed highly significant differences for each layer. In the 0-150 mm layer, DTNT recorded the lowest kPa (kilopascals) readings and was significantly lower than ZTCP, STCP, STLP, ZTLP and ZTNT $(\mathrm{P}<0.000)$. DTCP and DTLP were significantly lower $\mathrm{kPa}$ than ZTLP, STLP, STCP and ZTCP. ZTCP recorded the highest kPa reading and was significantly higher than ZTLP, ZTNT, STNT, DTLP, DTCP and DTNT. In the second layer (150-300 mm), similar trends were found and highly significant $(\mathrm{P}<0.000)$. STCP showed the highest $\mathrm{kPa}(3193.5 \mathrm{kPa})$ and was significantly higher than STNT, ZTNT, DTNT, DTLP and DTCP. In contrast, DTNT recorded the lowest reading (1268.4 kPa) and was significantly lower than ZTNT, STNT, ZTLP, ZTCP, STCP and STLP. STNT revealed significantly lower kPa than STLP, ZTCP and STCP. ZTNT penetrometer readings were significantly lower than all trafficked ZT and ST treatments. In the lower depth (300-450 mm), DTNT was significantly lower than STLP, STCP, ZTCP, ZTLP and STNT $(\mathrm{P}<0.000)$. 


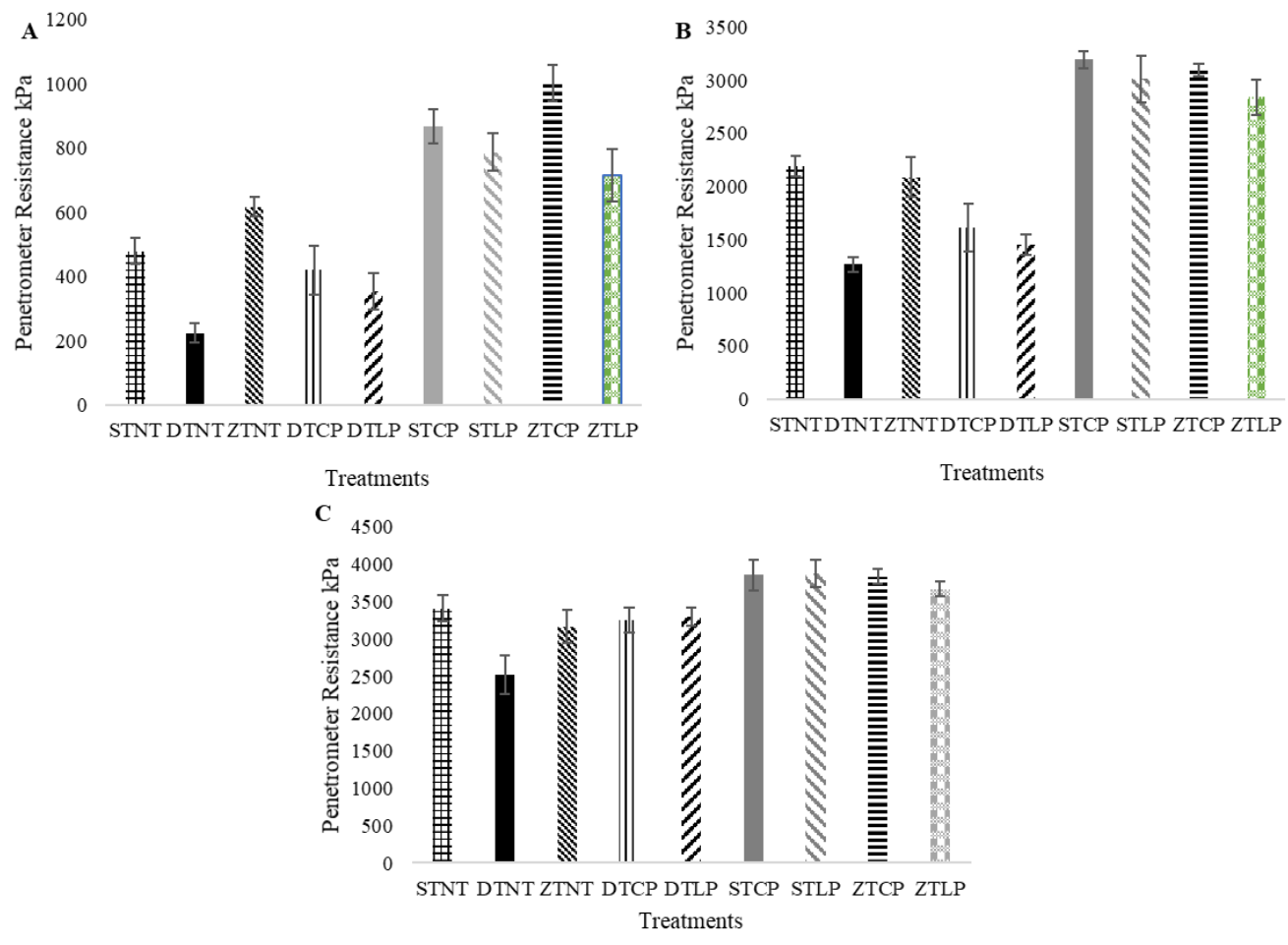

Figure 2. Penetration resistance for three layers (a) 0-150 mm (P<0.000), (b)150-300 mm (P<0.000) and (c) 300$450 \mathrm{~mm}(\mathrm{P}<0.000)$ during wheat tillering (GS25). Soil moisture conditions were at field capacity during sampling.

\subsubsection{Soil porosity}

The results of the ANOVA analysis of the CT-measured porosity $(0-220 \mathrm{~mm})$ are presented in Table 2. Soil porosity results were split into two soil layers of 0-100 mm and 100-200 mm respectively. In the top 0-100 mm layer, DTNT showed significantly higher total pore space $(\mathrm{P}<0.01)$ compared to all other treatments except ZTNT. Tillage had a significant effect on soil porosity in the no traffic samples in the 0-100 mm layer $(\mathrm{P}<0.05)$. Deep tillage with no traffic had higher soil porosity $(22.72 \%)$ than in shallow tillage (no traffic) $(10.58 \%)$. There was no significant difference between soil porosity under zero tillage and shallow tillage in the no traffic samples. Trafficking had a significant effect on overall porosity. In deep tillage treatments, overall porosity $22.72 \%$ (no traffic) was reduced to $8.08 \%$ (under low tyre pressure) and $6.50 \%$ under conventional tyre pressure. Traffic had little effect on shallow and zero tillage porosity in the top 0-100 $\mathrm{mm}$ when compared to the no traffic samples with small reductions in porosity. In the second examined layer, 100-200 $\mathrm{mm}$ zone, tillage and traffic were not significantly different $(\mathrm{P}<0.487)$. The percentage porosity shown in Table 2, indicate a sharp decline in the lower depth with only $9.02 \%$ in DTNT. DTCP treatments recorded the lowest porosity (3.96\%). 
Table 2. Soil porosity for tillage $\mathrm{x}$ traffic for two soil layers.

\begin{tabular}{|c|c|c|c|c|}
\hline ImageJ soil porosity $\% 0-100 \mathrm{~mm}$ & $n$ & No traffic & low tyre pressure & $\begin{array}{c}\text { Conventional tyre } \\
\text { pressure }\end{array}$ \\
\hline Deep & 4 & $22.72 \mathbf{a}$ & $8.08 \mathbf{b}$ & $6.50 \mathbf{b}$ \\
\hline Shallow & 4 & $10.58 \mathbf{b}$ & $8.64 \mathbf{b}$ & $7.23 \mathbf{b}$ \\
\hline Zero & 4 & $10.77 \mathbf{a b}$ & $8.41 \mathbf{b}$ & $8.49 \mathbf{b}$ \\
\hline \multicolumn{5}{|l|}{$\mathrm{P}<0.01$} \\
\hline $\begin{array}{l}\text { ImageJ Soil porosity } \% 100 \text { - } \\
200 \mathrm{~mm}\end{array}$ & $n$ & & & \\
\hline Deep & 4 & 9.02 & 6.16 & 3.96 \\
\hline Shallow & 4 & 4.06 & 6.44 & 5.32 \\
\hline Zero & 4 & 2.895 & 6.44 & 5.32 \\
\hline $\mathrm{P}<0.487$ & & & & \\
\hline
\end{tabular}

\subsubsection{Destructive $2 D$ root analysis}

The interaction between tillage system and trafficking protocols using destructive root measuring methods (WinRHIZO ${ }^{\mathrm{TM}}$ ) are shown in fig 3 for GS 25 and fig 4 for GS 61. At GS25, no significant differences were found between traffic and tillage treatments. However, the WinRHIZO ${ }^{\mathrm{TM}}$ analysis revealed a tendency towards increased root growth in no traffic treatments. At the later growth stage (GS61), Figure 3 depicts the results showing highly significant interactions between trafficking systems on root length density (RLD) $(\mathrm{P}<0.001)$ and root length $(\mathrm{P}<$ $0.001)$, root surface area $(\mathrm{P}<0.002)$ and root volume $(\mathrm{P}<0.05)$. DTNT showed significantly higher RLD, root surface area and root length compared to ZTCP, STCP and STLP. Root volume was significantly higher in DTNT over ZTCP and STCP. DTNT produced nearly double the root length compared to ZRCP. In contrast to DTCP, root surface area reduced by $36 \%$ compared to untrafficked areas (no traffic samples). In shallow and zero tillage, root surface area was reduced by $32 \%$ and $63.6 \%$ respectively in conventional pressure samples compared to untrafficked samples. There was no significant difference for root diameter and between all tillage and trafficking regimes. The results demonstrate that there was no significant difference in RLD at the tillering stage, nor could trends be found as roots were undeveloped. However, at anthesis, the RLD was significantly higher under nontrafficked tillage treatments when compared to DTCP, STCP and ZTCP (Fig 3b). 
https://doi.org/10.5194/soil-2021-129

Preprint. Discussion started: 30 November 2021

(c) Author(s) 2021. CC BY 4.0 License.
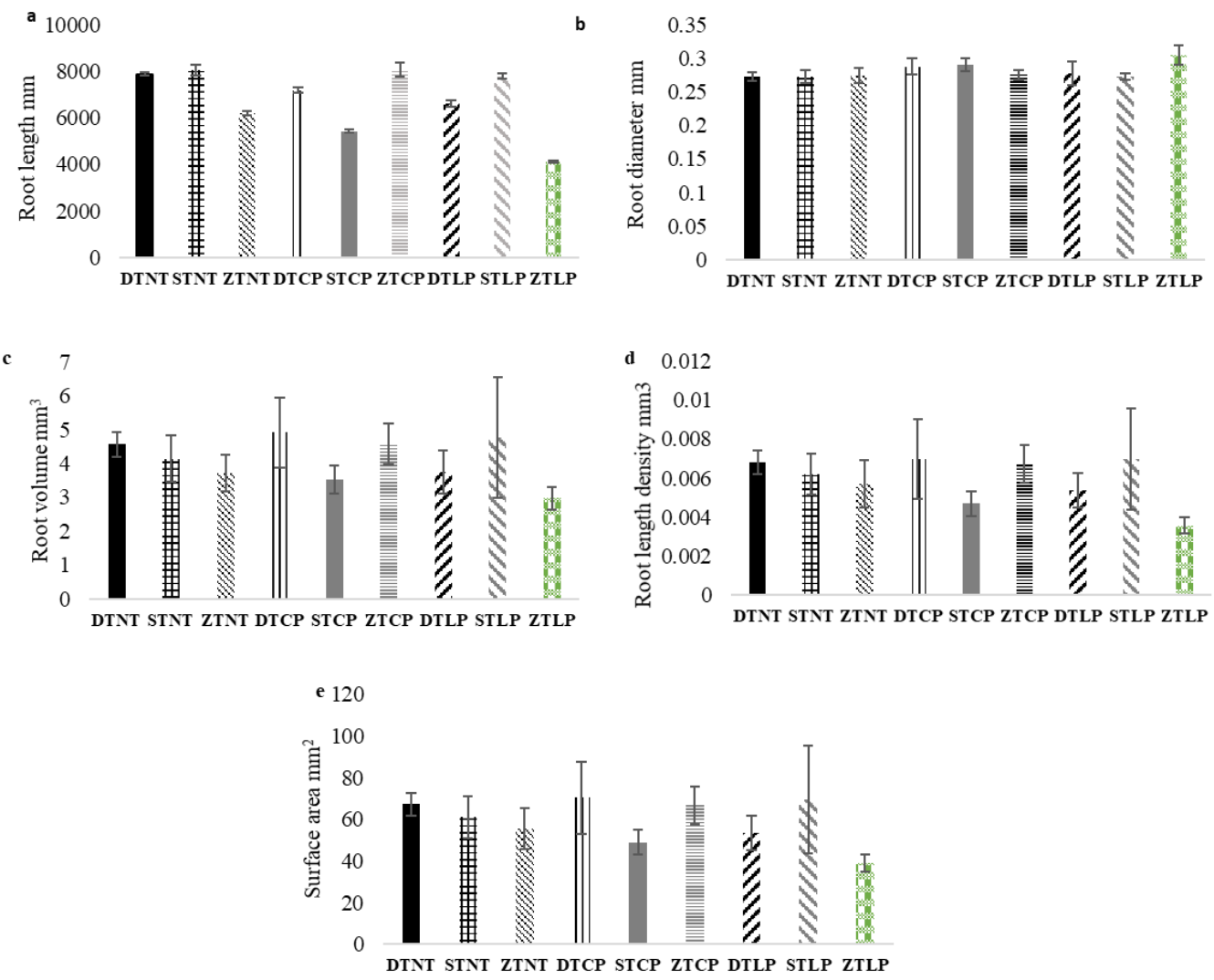

Figure 3. Tillering (GS25) root system architecture using destructive root method. (a) Root length (mm), (b) Root 


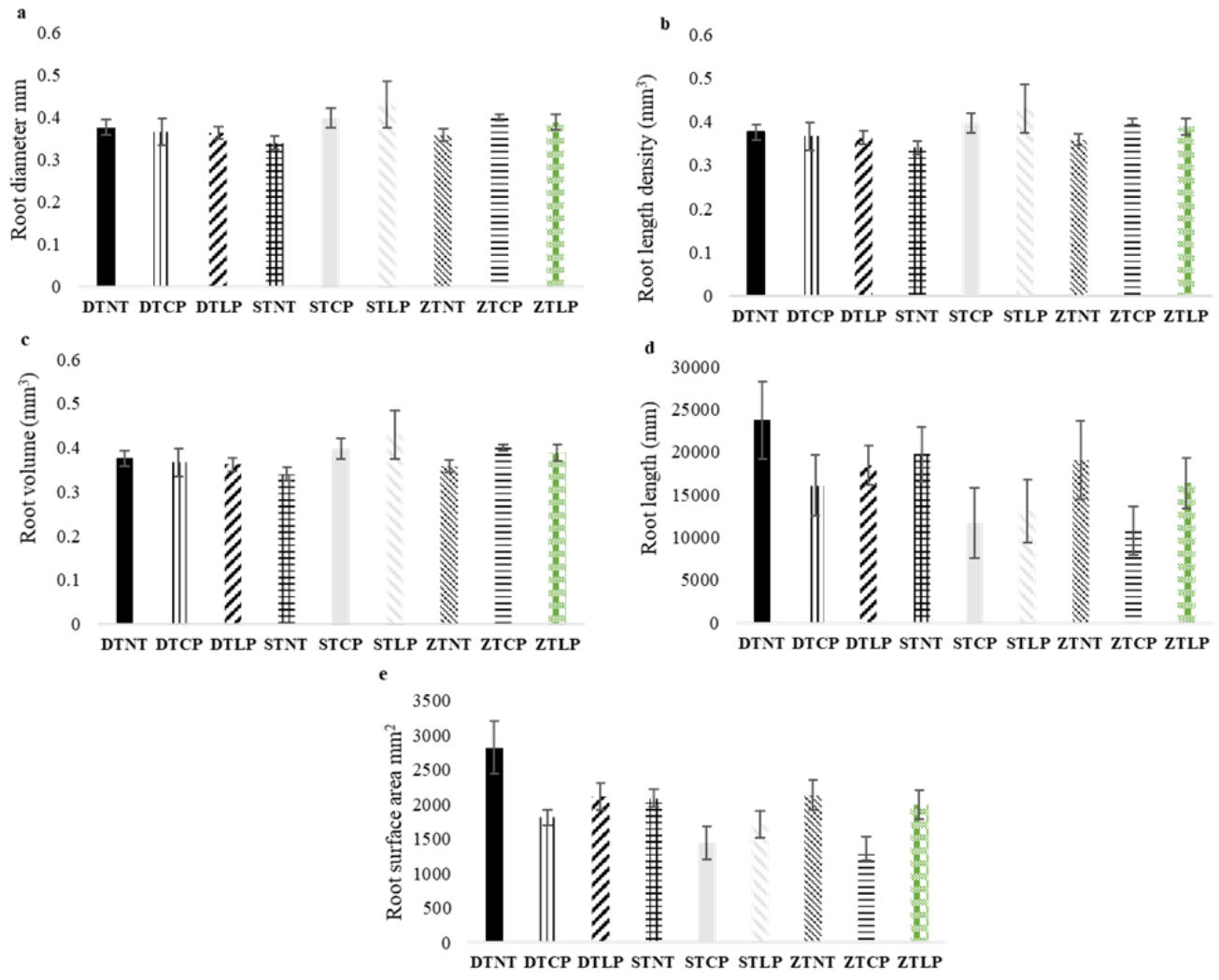

Figure 4. Flowering growth stage 61 root system architecture using destructive root method. (a) Root diameter, (b) Root length density $\left(\mathrm{mm}^{3}\right)$, (c) Root volume $\left(\mathrm{mm}^{3}\right),(\mathbf{d})$ root length $(\mathrm{mm}),(\mathbf{e})$ Root surface area $\left(\mathrm{mm}^{2}\right)$

\subsubsection{X-ray CT root analysis results}

Significant differences were found between trafficking treatments at GS61 for RLD and vertical root depth using non-destructive VGStudioMax 3.2 (Table 3). The X-ray CT scans revealed significantly longer vertical rooting (measured via the Z axis in VGStudioMax $\left.{ }^{\circledR}\right)$ in ZTNT $(112.7 \mathrm{~mm})$ compared to DTCP $(60.44 \mathrm{~mm})$, DTLP (66.96 $\mathrm{mm})$, STLP $(65.39 \mathrm{~mm})$ treatments $(\mathrm{P}<0.001)$. ZTNT showed significantly greater RLD $\left(0.000098 \mathrm{~mm} / \mathrm{m}^{3}\right)$ over DTCP $\left(0.000052 \mathrm{~mm} / \mathrm{m}^{3}\right)$, DTLP $\left(0.000058 \mathrm{~mm} / \mathrm{m}^{3}\right)$, STLP $\left(0.000058 \mathrm{~mm} / \mathrm{m}^{3}\right)$ and ZTCP $\left(0.000060 \mathrm{~mm} / \mathrm{m}^{3}\right)$ treatments $(\mathrm{P}<0.001)$. Root volume and surface area showed no significant difference using $\mathrm{X}$-ray $\mathrm{CT}$. However, similar trends were found to the conventional WinRHIZO ${ }^{\text {TM }}$ method. Trafficking had more of an influence on rooting than tillage method which did not have any significant effect on root parameters. As RLD is an important root trait commonly measured to estimate water uptake (White, Sylvester-Bradley and Berry, 2015), linear regression was used to verify the relationship between root depth and RLD. A significant relationship $(\mathrm{P}<0.001)$ was found with a coefficient of determination $R^{2}=0.54$ (Supplementary Fig. S2). 
https://doi.org/10.5194/soil-2021-129

Preprint. Discussion started: 30 November 2021

(c) Author(s) 2021. CC BY 4.0 License.

Table 3. Root system architecture using non-destructive method.

\begin{tabular}{|c|c|c|c|c|}
\hline \multirow[b]{2}{*}{ Tillage $x$ traffic } & \multicolumn{3}{|c|}{$\begin{array}{l}\text { Root system Architecture } \\
\text { flowering growth stage }\end{array}$} & \multirow[b]{2}{*}{ Root length density $(\mathrm{mm} / \mathrm{m} 3$} \\
\hline & Root volume mm3 & $\begin{array}{l}\text { t surface area } \\
\mathrm{mm} 2\end{array}$ & Length $(\mathrm{Z})$ axis (mm3) & \\
\hline DTNT & 3900.00 & 23448 & 96.1 ab & $0.000083 \mathbf{a b}$ \\
\hline STNT & 2648.00 & 17350 & 88.4 abc & $0.000077 \mathbf{a b}$ \\
\hline ZTNT & 3048.00 & 17907 & $112.7 \mathbf{a}$ & $0.000098 \mathbf{a}$ \\
\hline DTCP & 2276.00 & 12114 & $60.44 \mathrm{c}$ & $0.000052 \mathbf{b}$ \\
\hline DTLP & 3525.00 & 20269 & $66.96 \mathbf{b c}$ & $0.000058 \mathbf{b}$ \\
\hline STCP & 2900.00 & 18052 & 67 abc & $0.000058 \mathbf{a b}$ \\
\hline STLP & 2358.00 & 14211 & 65.39 bc & $0.000057 \mathbf{b}$ \\
\hline ZTCP & 2533.00 & 15040 & $69.43 \mathrm{abc}$ & $0.000060 \mathrm{~b}$ \\
\hline ZTLP & 4480.00 & 25104 & $97.89 \mathbf{a b}$ & $0.000085 \mathbf{a b}$ \\
\hline P value & NS & NS & 0.001 & 0.001 \\
\hline
\end{tabular}

408 *Significant differences between means are represented by different letters.

409 Figure 5 shows root biomass results for GS25 and GS61. No significant differences between treatments at GS25

$410 \quad(\mathrm{P}<0.848)$ were found. However, root biomass was significantly different for tillage $\mathrm{x}$ traffic with high confidence

411 level $(\mathrm{P}<0.001)$ at GS61. DTNT $(0.829 \mathrm{~g})$ showed significantly $(\mathrm{P}<0.001)$ greater root biomass, than STCP $(0.437$

$412 \mathrm{~g})$ and ZTCP $(0.4530 \mathrm{~g})$ treatments. DTNT did not significantly differ from ZTLP (0.7992 g), ZTNT (0.7939 g),

413 DTLP (0.6837 g), STNT (0.4991 g) and STLP (0.4923 g). The results show that, DTNT, ZTLP and ZTNT resulted

414 in nearly $50 \%$ greater root biomass over STCP and ZTCP treatments. Tillage treatments (center line where there

415 was no traffic effect) did not differ significantly with respect to root biomass. 

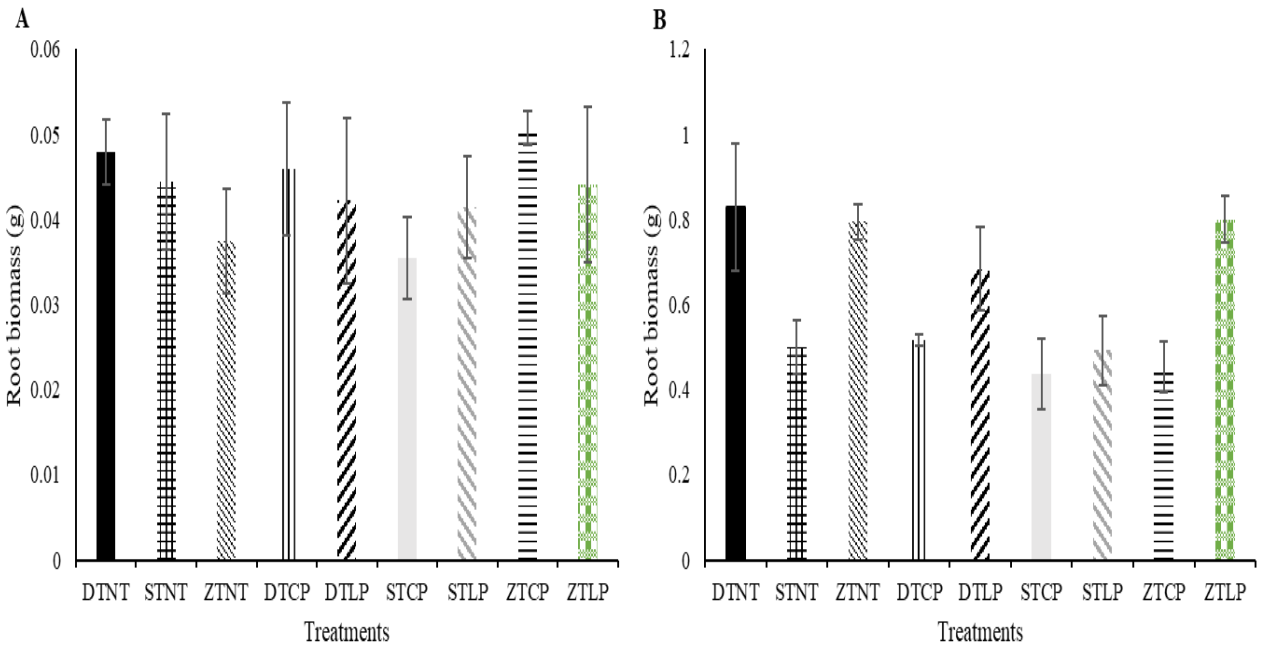

Figure 5. Root biomass at tillering (GS25) and flowering (GS61) for traffic and tillage treatments. Treatments represented by initials (Tillage: $\mathrm{D}=$ Deep, $\mathrm{S}=$ Shallow, $\mathrm{Z}=$ Zero), (Traffic: NT = No traffic, $\mathrm{LP}=$ Low pressure tyre, $\mathrm{CP}=$ Conventional pressure tyre).

\subsection{Crop yield}

Crop yield was highly significant between trafficking treatments and tillage $(\mathrm{P}<0.01)$ shown in Fig. 6. ZTLP had the highest yield $\left(11,385 \mathrm{~kg} \mathrm{ha}^{-1}\right)$ and was significantly greater than DTLP $\left(10,757 \mathrm{~kg} \mathrm{ha}^{-1}\right)$, STCP $\left(10,700 \mathrm{~kg} \mathrm{ha}^{-}\right.$ $\left.{ }^{1}\right)$, STNT $\left(10,678 \mathrm{~kg} \mathrm{ha}^{-1}\right)$, STLP $\left(10,638 \mathrm{~kg} \mathrm{ha}^{-1}\right)$ and DTCP $\left(10,613 \mathrm{~kg} \mathrm{ha}^{-1}\right)$. All three zero tillage treatments trended higher than deep tillage and shallow tillage treatments. ZTLP showed a $500 \mathrm{~kg} \mathrm{ha}^{-1}$ yield advantage over DTNT (NS) and between 628 - $772 \mathrm{~kg} \mathrm{ha}^{-1}$ over trafficked treatments and STNT with high significance. In general, this study did not show a trend in yield between conventional and low tyre pressure treatments. For deep tillage, conventional tyre pressure reduced crop yield compared to low tyre pressure by $\left.144 \mathrm{~kg} \mathrm{ha}^{-1}\right)(1.34 \%)$. When compared to the no traffic sample, conventional tyre pressure consistently reduced yield by $\left.272 \mathrm{~kg} \mathrm{ha}^{-1}\right)(2.5 \%)$ in deep tillage. Although not significant, trafficking trended towards improving yield by $\left.30 \mathrm{~kg} \mathrm{ha}^{-1}\right)(0.03 \%)$ using conventional tyre pressure and $\left.340 \mathrm{~kg} \mathrm{ha}^{-1}\right)(3.07 \%)$ using low tyre pressure. No trends were found in shallow tillage treatments. Linear regression of root depth using X-ray CT showed a significant relationship to crop yield $(\mathrm{P}<0.001)$ and positive correlation $(\mathrm{r}=0.54)$. However, the coefficient of determination was low $\mathrm{R}^{2}=0.3094$ (Fig. S3). Moreover, regression analysis also showed a significant relationship between root biomass and crop yield $(\mathrm{P}<0.01)$. However, the correlation between the two variables was weaker $(r=0.43)$ (coefficient of variance $\mathrm{R}^{2}=0.1859$. This indicates that root depth is a stronger predictor of crop yield. 


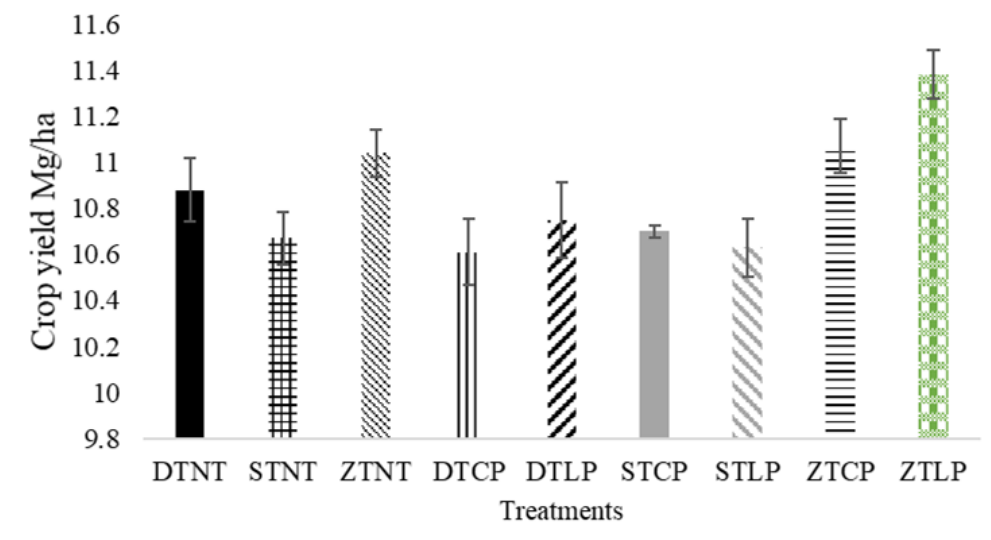

Figure 6. Crop yield in $\mathrm{Mg} / \mathrm{ha}$ for traffic $\mathrm{x}$ tillage treatments.

\section{Discussion}

\subsubsection{Soil physical responses to tillage \& trafficking}

In line with this papers hypothesis, trafficking effects were more influential on crop and root performance than tillage system. The presence of wheeled areas in both zero and deep cultivation treatments increased soil bulk density significantly in deep tillage treatments (Fig. 1). Previous studies have shown that zero tillage systems increase in bulk density, penetration resistance and reduce in porosity in the early years of adoption from conventional tillage systems (Christian and Ball, 1994; Six et al., 2004; Mangalassery et al.,2014a; Smith, 2016). Vogeler et al., (2009) showed that bulk density is higher under conservation tillage methods in the top $100 \mathrm{~mm}$ layer during the first five years of adoption from conventional systems. Indeed, Soane et al., (2012) reported that significant regeneration of soil structure requires a three-year period from tillage depending on previous historic land management practice. Moreover, values decrease in the long term with multiple benefits including improved saturated conductivity, soil organic matter and air permeability in lower soil horizons. Arvidsson, 1998 showed that soils with $<30 \mathrm{~g} \mathrm{~kg}^{-1}$ of organic matter were likely to suffer $11 \%$ higher crop yield loss due to compaction using uniaxial compression tests. It is plausible that the actions of soil fauna such as earthworms and old root channels could have reduced bulk density over time (Fig. 7) as identified by (Angers and Caron, 1998). Roots promote soil structural formation through increasing soil aggregation. Root mucilage production, root hair formation, and localised wetting and drying cycles encourage a reduction in soil bulk density (Bengough, 2012).

Our data shows similar findings with zero and deep tillage significantly reduced bulk density values in untrafficked zones. However, in trafficked treatments, high tyre pressure combined with deep tillage treatments resulted in higher bulk density values due to the loss of inherent strength by tilled soil, resulting in compression of soil particles (Raper, 2005; Soane, Godwin and Spoor, 1986). Chan et al., (2006) observed that trafficking after deep tillage increased bulk density values from $1.27 \mathrm{Mg} \mathrm{m}^{-3}$ to $1.54 \mathrm{Mg} \mathrm{m}^{-3}$, emphasizing the effect of trafficking on the reduced bearing capacity of the deep tilled soil. The optimum soil density has been reported to differ 
between soil types in previous studies. Indeed, Czyż, (2004) established a soil type interaction between crop yield,

466 bulk density and root mass concluding with sandy loam soils (similar to this study) having an optimum bulk

467 density value of $1.54-1.66 \mathrm{Mg} \mathrm{m}^{-3}$. Yet, in this study, root biomass was significantly reduced with treatments

468 displaying similar soil density values to that reported optimum. Although conventional pressure tyres significantly

469 affected zero tillage in the $100-200 \mathrm{~mm}$ layer, trafficking affected the $0-200 \mathrm{~mm}$ later under deep tillage. In

470 shallow tillage treatments, the top $0-100 \mathrm{~mm}$ layer was considerably impacted by high tyre pressure.

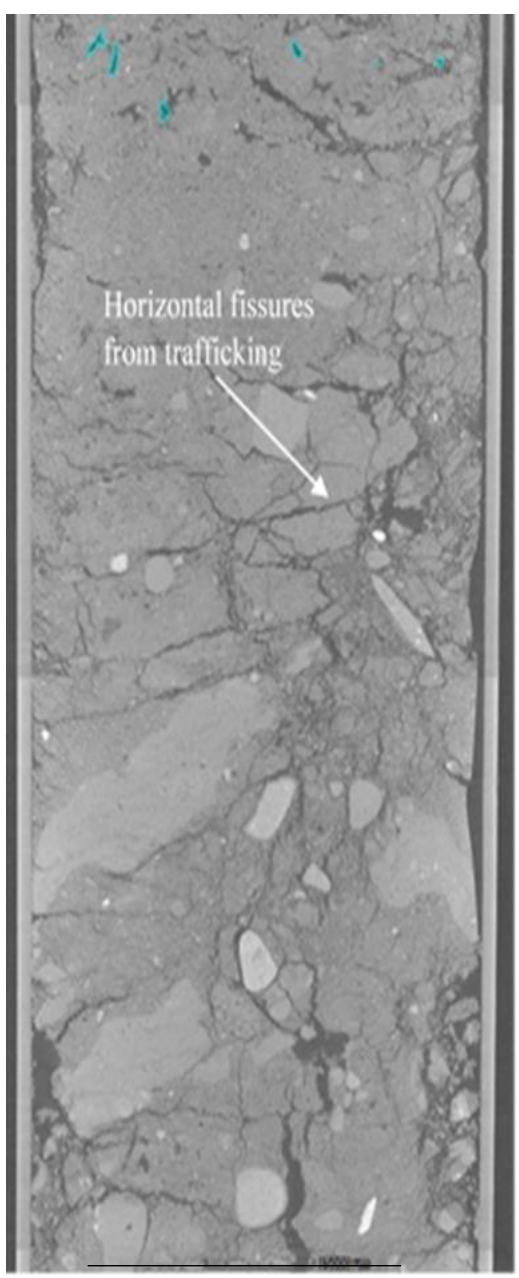

(a)

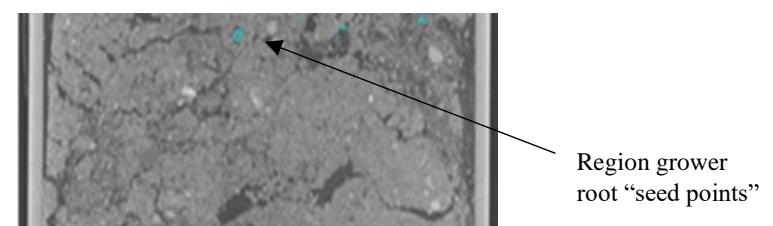

root "seed points"

Figure 7. Vertical view of X-ray CT images through centre of soil core using VGStudioMax ${ }^{\circledR}$ software for (a) 
Sandy soils due to their adhesive and coarse grain nature, have reduced porosity, including lower levels of micropores compared to loamy soils (Arvidsson, 1998). The aggregation potential in this sandy loam soil is low. In the presence of plants, porosity and pore connectivity as shown to reduce further compared to clay cohesive soils which tend to increase in porosity through flocculation and aggregation (Bacq-Labreuil et al., 2018). Here, we found soil porosity to be low in general across all treatments. When comparing cultivation systems, we found that shallow tillage in the $0-100 \mathrm{~mm}$ layer had significantly lower porosity (10.58\%) compared to deep tillage $(22.72 \%)$. Although zero tillage recorded low porosity values also (10.72\%), it was not significantly different to the other two systems. Compared to non-trafficked treatments, trafficked soil in general caused a sharp decline in soil porosity in the top 0-100 mm layer. Tyre inflation pressure is one of the key contributors to soil stress in the 100 to $1000 \mathrm{~mm}$ layer (Botta et al., 2008). The effect of re-compaction from trafficking after cultivation was often worse in deep tillage treatments, with a lower percentage porosity than in zero and shallow tillage (Table 2 for DTLP and DTCP treatments). In deeply cultivated soils, water infiltration rates can be reduced by up to $82 \%$ after a single wheelings (Chyba, 2012), which has agronomic implications such as reduced water and nutrient use efficiency by up to $22 \%$ thus, potentially resulting in crop yield penalties of up to $38 \%$ ( Ishaq et al., 2001) . Yield effects by trafficking were modest in our study due to low soil moisture conditions during sowing in autumn 2018 (Met office, 2019). Dry soil has increased soil strength, reducing the effects of soil compaction as the soil load support capacity would have increased thus, increasing permissible ground pressure (Hamza and Anderson, 2005).

A key characteristic of zero tilled soils is a change in soil pore architecture with vertically orientated fissures connected down through the soil profile created by biopores (Fig. 7). Similar findings have resulted in reduced $\mathrm{CO}_{2}$ fluxes and increased saturated hydraulic conductivity by surface-connected porosity (Cooper et al., 2021). The same study found similar soil porosity levels between conventional and zero tillage with zero tillage total porosity ranging from $<5 \%, 10 \%$ and $12 \%$ on average over $1-5,6-10$ and $11-15$ years respectively. The significant increase in deep tillage soil porosity substantially increases soil respiration, resulting in up to 13.8 times higher $\mathrm{CO}_{2}$ emissions through increased oxidation and carbon breakdown (Reicosky et al., 1999). The lower porosities in zero and shallow tilled soils reduces space for gas exchange, reducing soil respiration and supporting carbon sequestration, thus increasing recalcitrant levels of carbon in soil. Mangalassery et al., (2014) found similar porosity results using X-ray CT methods to measure the effect of tillage method on greenhouse gas emissions, finding significantly higher porosity in tilled soil (13.6\%) compared to zero tilled soil (9.6\%) in the top 0-100 mm layer. However, in deeper soil horizons, no difference could be found between tillage system. The findings in this experiment agree with that study, showing both tillage methods did not differ significantly in the 100-200 mm layer with lower soil porosities recorded. 
https://doi.org/10.5194/soil-2021-129

Preprint. Discussion started: 30 November 2021

(c) Author(s) 2021. CC BY 4.0 License.

$514 \quad$ 4.1.3 Penetrometer responses to tillage and traffic

515

516 Penetrometer resistance (PR) is a useful parameter for evaluation of soil physical resistance to root growth (Otto

517 et al., 2011). In general, trafficking had a considerable influence on soil PR in this study as depicted in fig. 8. The

518 greatest contrast in soil penetration resistance was between trafficked and un-trafficked soil with zero tillage

519 showing the highest resistance under conventional tyre pressure. Recent studies have shown that roots can exploit

520 pores and bypass layers of strong soil (Atkinson et al., 2020). Axial pressure from repeated trafficking in ZTCP

521 resulted in the highest PR values. However, root depth was less affected in contrast to STCP and DTCP. This

522 might explain why roots could exploit existing pore networks in undisturbed soils compared to tillage treatments.

523 In the middle layer examined, shallow till conventional pressure treatments suffered from a tillage pan effect

524 shown in Fig. 7. In fact, all trafficked zero and shallow tillage systems resulted in PR values beyond 2,000 kPa, a

525 threshold level which several studies show there is a reduction in root growth (da Silva, Kay and Perfect, 1994;

526 Lapen et al., 2004; Tormena, da Silva and Libardi, 1999). A compact zone at shallow depths is detrimental to

527 plant growth and crop yield in rainfed temperate climates when short term droughts occur (Campbell, Reicosky

528 and Doty, 1974). 

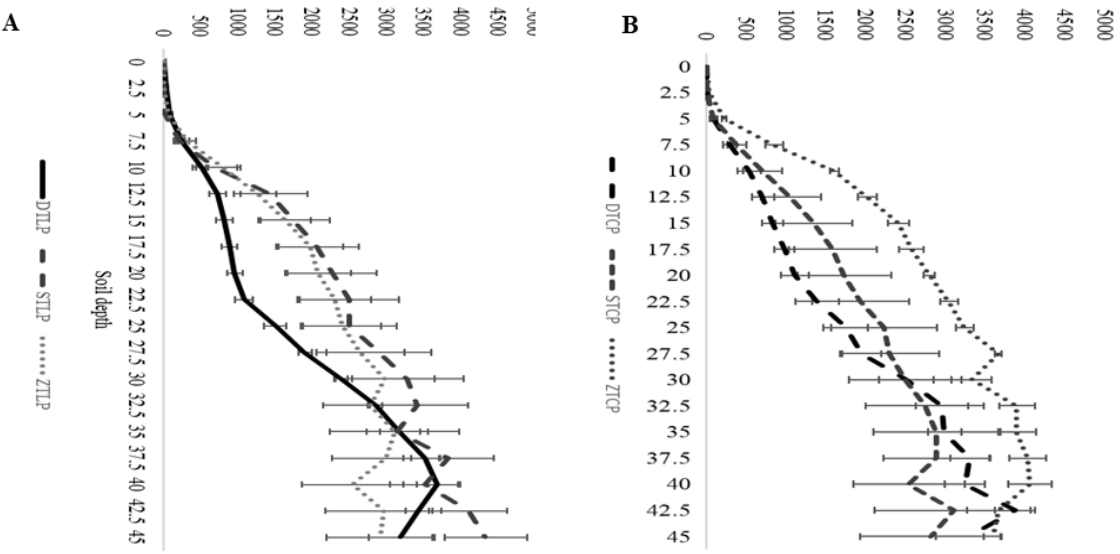

C

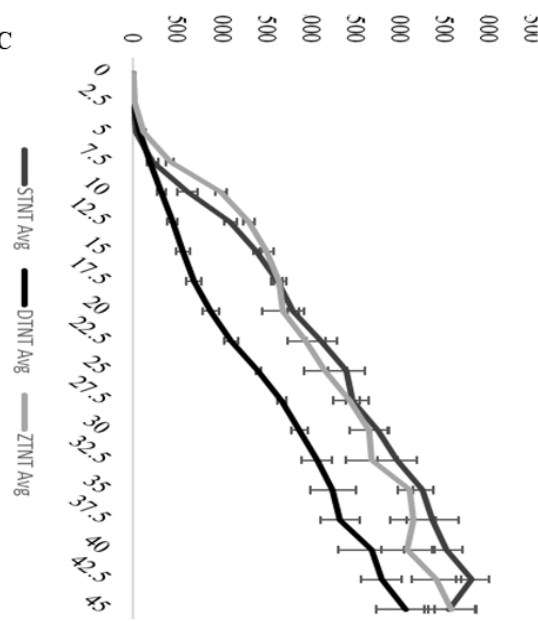

D

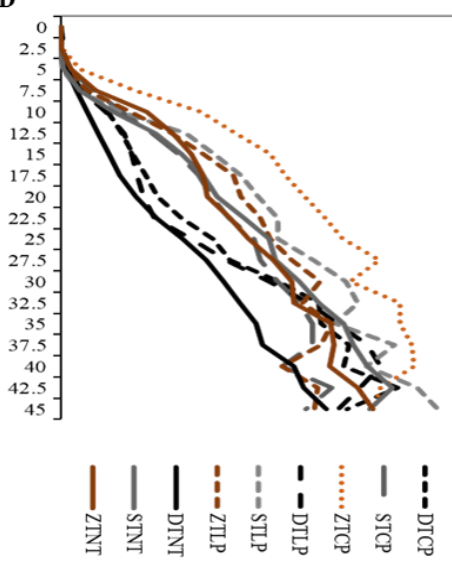

Figure 8. Penetration resistance $(\mathrm{kPa})$ for tillage and traffic treatments at soil depths of $0-450 \mathrm{~mm}$. $\mathrm{X}$ axis depicts soil depth. Y axis depicts Soil penetration resistance $(\mathrm{kPa})$. Treatments represented by initials (Tillage: $\mathrm{D}=$ Deep, $\mathrm{S}=$ Shallow, $\mathrm{Z}=$ Zero), (Traffic: NT = No traffic, $\mathrm{LP}=$ Low pressure tyre, $\mathrm{CP}=$ Conventional pressure tyre). $\mathbf{A}$ low tyre pressure, $\mathbf{B}$ conventional tyre pressure, $\mathbf{C}$ no traffic and $\mathbf{D}$ traffic $\mathbf{x}$ tillage treatments combined.

\subsection{Root system architecture responses to tillage and traffic}

The 'hidden half' (i.e. roots) of plants are difficult to interpret in field studies (Lynch and Brown, 2001). A large root system is characterized by large biomass, root length and root length density (Ehdaie et al., 2010; Hamblin and Tennant, 1987). Root biomass was an important indicator of root size, showing treatment effect at anthesis compared to the tillering stage. In general, root biomass had a positive relationship with grain yield. Zero tillage treatments both untrafficked and trafficked at low pressure had greater root biomass over all shallow tillage 
542

treatments and deep till trafficked at conventional pressure. Although deep tillage treatments with no traffic had the highest root biomass by GS61, it did not achieve the highest yield. No significant difference in root biomass was found between tillage treatments in untrafficked samples, confirming that roots are more sensitive to trafficking than tillage method. The compaction effects of trafficking on soil structure exacerbated the impact on rooting in general. Typically, studies report shallower rooting, increases in root diameter and decreased axial and lateral rooting (Grzesiak et al., 2014). Due to the high moisture deficits depicted in (Fig S1) experienced during April and May 2019, it is likely that the deeper vertical rooting in zero tillage treatments retained more moisture at depth compared to other establishment methods.

Traffic significantly affected root volume, root surface area, root length and RLD in shallow tillage treatments and zero tilled treatments trafficked at conventional pressure. RLD is an important parameter for characterizing root growth (Doussan et al., 2006) and has been used in previous studies as a key root parameter for modelling water uptake (Tinker and Nye, 2000; Javaux et al., 2013). Munos-Romero et al., (2010) and Chakraborty et al., (2008) results indicate that RLD is a positive predictor of crop yield. Although RLD had a positive correlation with crop yield in this study, root depth (using X-ray) displayed a much stronger relationship with crop yield (fig. S3). When comparing the highest root biomass (under deep tillage with no traffic) and bulk density results in the 100-200 mm layer, we found a reduction in root biomass when trafficked under conventional pressure by $28 \%$ in deep tillage under conventional pressure $\left(B D=1.66 \mathrm{~g} \mathrm{~cm}^{-3}\right), 37 \%$ in shallow till conventional pressure $\left(1.437 \mathrm{~g} \mathrm{~cm}^{-3}\right)$ and $39 \%$ in zero tillage conventional pressure $\left(1.583 \mathrm{~g} \mathrm{~cm}^{-3}\right)$ treatments. Colombi and Walter, (2017) observed decreased shoot dry weights in pot studies by 19 and $82 \%$ under moderate $\left(1.45 \mathrm{~g} \mathrm{~cm}^{-3}\right)$ and high $\left(1.6 \mathrm{~g} \mathrm{~cm}^{-3}\right)$ soil strength conditions. In the same study root dry weight was also reduced by 36 and $87 \%$ under the same soil strength conditions. Shallow tillage had the lowest root biomass in both trafficked and untrafficked treatments. Shallow tillage treatments suffered from visible horizontal fissures or "tillage pan" in Fig 10 , causing significantly reduced rooting compared to deep tillage treatments. Moreover, a combination of $<10 \%$ porosity and PR reaching $>2,000 \mathrm{kPa}$ in the $100-200 \mathrm{~mm}$ layer, it is likely that roots may also have suffered from anaerobic conditions due to poor infiltration rates through the tillage pan during heavy rainfall events. Conversely, root impedance may have occurred during drought periods through May and June (Batey, 2009). Alameda, Anten and Villar, (2012) proposed that axial growth suffers more than radial root growth. These effects of increased PR and soil bulk density were observed underin the current study. However, the increase in root diameter reported by several authors was not detected here (Chen et al., 2014; Lipiec et al., 2012; Tracy et al., 2012; Alameda, Anten and Villar, 2012).

\section{$4.32 D \& 3 D$ imaging for studying root-soil relationships}

Due to the complexity of measuring root systems, two methods were conducted to provide comprehensive analysis. Important topology (root networks) and geometrical (physical positions) characteristics of wheat rooting using X-ray CT were found in this study. A strong significant relationship between RLD (WinRHIZO ${ }^{\mathrm{TM}}$ ) and root depth (X-ray CT) was found (fig. S2) validating the suitability of image analysis methods in field studies. Further, root depth showed the strongest correlation with crop yield compared to root biomass and RLD (fig. S3). 
Moreover, the large environmental variance (low $\mathrm{r}$ number) in root relationships may have been caused by spatial effects reported in previous studies ( Guo et al., 2020; Zhou et al., 2021). Compared to traditional 2D WinRHIZO $^{\mathrm{TM}}$ analyses, the significant difference found with in-situ root depth between treatments using X-ray CT was not detected by destructive WinRHIZO ${ }^{\mathrm{TM}}$ analysis (i.e., it involves the washing of soil from root material, thus losing important architectural data). Destructive root analysis showed evidence of superior rooting properties under deep tillage treatments (e.g., root length density and root volume). Visualizing important behaviors of wheat rooting in field scale trials, highlights the importance of root depth to sustain high yields in drought conditions. Figure 9 depicts significantly longer root length in zero tillage treatments compared to trafficked deep and shallow tillage, with trafficked treatments roots were generally confined to the top 0-50 $\mathrm{mm}$ of soil. In general, root length rarely surpassed $100 \mathrm{~mm}$ in depth. This was partly due to insufficient resolution available with the X-ray CT scanner to capture finer root materials (Pfeifer et al., 2015).

In general, both root analysis methods showed agreement in the results. Zero tillage treatments had significantly deeper rooting over shallow tillage and deep tillage trafficked treatments. Using the WinRhizo ${ }^{\mathrm{TM}}$ method, untrafficked deep tillage treatments showed superior root length. Similar disagreements in findings between methods could be explained by the difference in methodology between the two imaging approaches as $\mathrm{X}$-ray CT is 3D and scans roots in soil whilst, WinRhizo ${ }^{\mathrm{TM}}$ is 2D and scans washed roots (Tracy et al., 2012). Root volume and surface area were also examined using X-ray CT. In contrast to the WinRhizo ${ }^{\mathrm{TM}}$ analysis, no significant differences could be detected between treatments. The root volumes obtained by the WinRhizo ${ }^{\mathrm{TM}}$ were much greater than the volumes attained from the X-ray CT scan. The difference can be attributed by much clearer contrasts between air and root material with the destructive method compared to limitations with resolution and
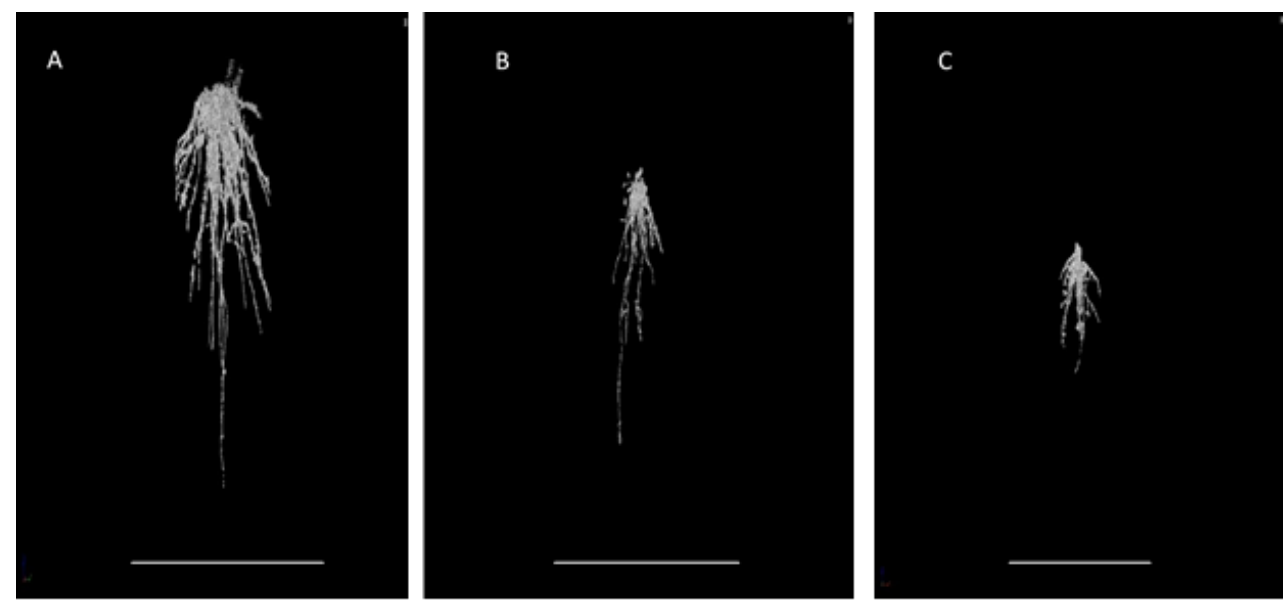

Figure 9. Root system architecture of winter wheat during anthesis for (a) Deep tillage no traffic, (b) Zero tillage low tyre pressure and (c) deep tillage conventional tyre pressure. (a) and (b) showed significantly longer root length on the primary axis compared to (c) deep tillage trafficked treatments. Scale bar $=70 \mathrm{~mm}$. 
613 In the present study, it was found that long term zero tillage plots under low tyre pressure increased yield by up

614

615

616 to $0.772 \mathrm{Mt} \mathrm{ha}^{-1}$ compared to the deep tillage conventional tyre pressure treatments. All zero tillage treatments yielded over $11 \mathrm{Mt} \mathrm{ha}^{-1}$ compared to deep and shallow tillage treatments (10.71 $\left.\mathrm{Mt} \mathrm{ha}^{-1} \mathrm{mean}\right)$. Evidence using data collected from the X-ray CT scans showed deeper vertical rooting in zero tillage plots compared to shallow and deep tillage treatments (Fig. 9). Coupled with deeper rooting, zero tillage no traffic treatments had significantly lower bulk density than deep tillage conventional pressure plots. Munoz-Romero et al., (2010) reported a yield increase of $0.5 \mathrm{Mt} \mathrm{ha}^{-1}$ in zero tillage compared to conventional tillage which was associated with greater water use and increased water use efficiency, similar to (Chakraborty et al., 2008). Improvements in moisture retention, soil pore structures and reduced soil compaction under zero-tillage, may also have contributed to a yield increase over conventionally tilled treatments.

It is possible that the lower levels of porosity found in zero tillage aided with water retention during drought periods on the highly sandy soil in this trial. Coupled with the development of vertically oriented soil structural characteristics attributed to earthworm activity and old root channels (Fig 7), the zero tillage treatments may also have had increased access to water by roots at lower soil horizons. Indeed, biopores benefit root growth by altering the surrounding chemical, physical and biological properties of soil ( Stroud et al., 2017; Banfield et al., 2017). Thus providing macropore pathways with lower mechanical resistance in which deeper rooting preferentially grow towards (Zhou et al., 2021). In contrast, deep cultivation created a porous structure which has shown to increase respiration of aerobic microorganisms, improving the flow of air and water thus increasing $\mathrm{CO}_{2}$ emissions ( Mangalassery et al., 2014). Crop yield was influenced less in zero tillage treatments by trafficking than the other tillage treatments. The lower sensitivity to compaction in zero tillage is attributed to an elastic behavior or increase in bearing capacity, with soil acquiring similar structural properties to grassland soil (Ehlers and Claupein, 1994). 
671

\section{Conclusion}

The results from this research highlight the importance of traffic management for improving crop productivity. Physical and visual implications of soil compaction on the soil profile were demonstrated in this study, signifying the implications of tyre pressure on root growth. High tyre pressure significantly reduced root development in all tillage treatments. However, deep, and shallow tillage systems were more influenced by compaction with roots confined to the top $0-60 \mathrm{~mm}$ thus, reducing primary vertical rooting and inhibiting roots access to deeper soil moisture reserves. The highly significant impact on crop yield was highlighted by the strong relationship between root depth and crop yield. The visible effects of trafficking on the soil profile depicted through X-ray CT, provides evidence of the damage modern farm machinery can cause for root resource capture, leading to potential increased drought stress and yield loss in crop production. This long-term trial site has shown that zero tillage does not affect root growth, in fact, reduced bulk density, improved grain yield and rooting depth significantly through deeply connected vertical soil pore fissures created by earthworms and old root channels. These findings suggest that scientists and farmers should focus on designing improved zero tillage cropping systems, managing field trafficking protocols. Furthermore, this research shows that the combination of X-ray CT scanning along with traditional destructive methods provide a robust method for assessing in field rooting for future crop breeding initiatives and soil management practice. This research concludes that little differences were found between deep tillage and zero tillage methods in the absence of traffic in terms of overall physical root growth. However, in abundance of biopores and increased soil bearing capacity to withstand machinery traffic in in zero tillage systems increased rooting depth and moisture retention during the growing season.

Supplement. The supplement related to this article is available in a separate word file as per submission.

Author contributions. KMc and ST conceived the experiment. DH \& MH carried out sampling and soil analysis. DH processed and analysed all samples. DH analysed and interpreted the data and wrote the manuscript. All authors contributed to the data, providing interpretation and comments to the manuscript.

Competing interests. The authors declare that they have no conflict of interest

\footnotetext{
Acknowledgements. This research took samples from a long term tillage and traffic experiment site in Harper Adams University. Long term crop rotation treatments at the Large Marsh site on the University grounds are managed and maintained by the agricultural staff at the university.
} 
676 AHDB.: Wheat growth guide, AHDB Cereals \& Oilseeds, Stoneleigh Park, Kenilworth, Warwickshire, CV8

677 2TL: AHDB, 2018.

Akker, J. J. H. v. d. and Canarache, A.: 'Two European concerted actions on subsoil compaction', Wageningen Environmental Research, 42(1), pp. 15-22, 2001.Alameda, D., Anten, N. P. R. and Villar, R. 'Soil compaction effects on growth and root traits of tobacco depend on light, water regime and mechanical stress', Soil and Tillage Research, 120, pp. 121-129, 2012.

Amelung, W., Bossio, D., de Vires, W., Kogel-Knabner, I., Lehmann, J., Amundson, R., Bol, R., Collins, C., Lal, R., Leifeld, J., Minasny, B., Pan, G., Paustian, K., Rumpel, C., Sanderman, J., van Groenigen, J.W., Mooney, S., van Wesemael, B., Wander, M., Chabbi, A.: Towards a global-scale soil climate mitigation strategy, Nature Communications, 11(1), pp. 5427, 2020.

Angers, D. A. and Caron, J.: Plant-induced Changes in Soil Structure: Processes and Feedbacks, Biogeochemistry, 42(1), pp. 55-72, 1998.

Arvidsson, J.: Direct drilling possible with a good preceding crop, Swedish Rural Econ. Agric. Soc, 4, pp. 9-10, 2010.

Arvidsson, J.: Influence of soil texture and organic matter content on bulk density, air content, compression index and crop yield in field and laboratory compression experiments, Soil and Tillage Research, 49(1), pp. 159-170, https://doi.org/10.1016/S0167-1987(98)00164-0, 1998.

Arvidsson, J. and Keller, T.: Soil stress as affected by wheel load and tyre inflation pressure', Soil and Tillage Research, 96(1), pp. 284-291, https://doi.org/10.1016/j.still.2007.06.012, 2007.

Arvidsson, J.: Direct drilling possible with a good preceding crop, Swedish Rural Econ. Agric. Soc, 4, pp. 9-10, 2010.

Atkinson, J. A., Hawkesford, M. J., Whalley, W. R., Zhou, H., Mooney, S. J.: Soil strength influences wheat root interactions with soil macropores', Plant, Cell \& Environment, 43(1), pp. 235-245, https://doi.org/10.1111/pce.13659, 2020.

Bacq-Labreuil, A., Crawford, J. W., Mooney, S., Neal, A.L., Akkari, E., Mcauliffe, C., Zhang, X. X., RedmileGordon, M. A., Ritz, K.: Effects of cropping systems upon the three-dimensional architecture of soil systems are modulated by texture, Geoderma, 332, pp. 73-83, https://doi.org/10.1016/j.geogerma.2018.07.002, 2018.

Banfield, C. C., Dippold, M. A., Pausch, J., Hoang, D. T., Kuzyakov, Y.: Biopore history determines the microbial community composition in subsoil hotspots', Biology and Fertility of Soils, 53(5), pp. 573-588, 2017.

Batey, T.: Soil compaction and soil management - a review, Soil Use and Management, 25(4), pp. 335-345, https://doi.org/10.1111/j.1475-2743.2009.00236.x, 2009.

Bengough, A. G., McKenzie, B. M., Hallett, P. D., Valentine, T. A.: Root elongation, water stress, and mechanical impedance: a review of limiting stresses and beneficial root tip traits', Journal of Experimental Botany, 62(1), pp. 59-68, https://doi.org/10.1093/jxb/erq350, 2011.

Bengough, A. G.: Water Dynamics of the Root Zone: Rhizosphere Biophysics and Its Control on Soil Hydrology', Vadose Zone Journal, 11, https://doi.org/10.2136/vzj2011.0111, 2012. 
Boguzas, V. and Hakansson, I. 'Barley yield losses simulation under Lithuanian conditions using the Swedish soil compaction model', Soil management department, Lithuanian University of Agriculture, pp. 24-28, 2001.

Boguzas, V., Kairyte, A., Jodaugiene, D., Lukosiunas, K.: Effect of reduced and no-tillage, straw and green manure management on soil physical properties and earthworms., Agronomy, pp. 1566-1577, 2006.

Botta, G. F., Rivero, D., Tourn, M., Bellora Melcon, F., Pozzolo, O., Nardon, G., Balbuena, R., Tolon Becerra, A., Rosatto, H., Stadler, S.: Soil compaction produced by tractor with radial and cross-ply tyres in two tillage regimes', Soil and Tillage Research, 101(1), pp. 44-51, 10.1016/j.still.2008.06.001, 2008.

Campbell, D. J. and Henshall, J. K.: Bulk density, in Smith, K.A. \& Mullins, C.E. (eds.) Soil and Environment Analysis Physical Methods. New York, 2000.

Campbell, R. B., Reicosky, D. C. and Doty, C. W.: Physical properties and tillage of palendults in the southeastern coastal plains; propriete physique et labour des ultisols du sud des plaines cotieres, 1974.

Chakraborty, D., Nagarajan, S., Aggarwal, P., Gupta, V. K., Tomar, R. K., Garg, R. N., Sahoo, R. N., Sarkar, A., Chopra, U. K., Sundara Sarma, K. S., Kalra, N.: Effect of mulching on soil and plant water status, and the growth and yield of wheat (Triticum aestivum L.) in a semi-arid environment, Agricultural Water Management, 95(12), pp. 1323-1334, 2008.

Chamen, T.: Controlled traffic farming on a field scale in the UK, Soil management for sustainability, Advances in Geoecology, 38, pp. 251-260, 2006.

Chamen, W. C. T.: The effects of low and controlled traffic systems on soil physical properties, yields and the profitability of cereal crops on different soil types. $\mathrm{PhD}$, Cranfield University, 2011.

Chamen, W. C. T., Moxey, A. P., Towers, W., Balana, B., Hallett, P. D.: Mitigating arable soil compaction: A review and analysis of available cost and benefit data, Soil and Tillage Research, 146, pp. 10-25, doi: 10.1016/j.still.2014.09.011, 2015.

Chan, K. Y., Oates, A., Swan, A. D., Hayes, R. C., Dear, B.S., Peoples, M. B.: Agronomic consequences of tractor wheel compaction on a clay soil, Soil and Tillage Research, 89(1), pp. 13-21, http://hdl.handle.net/102.100.100/174858?index=1, 2006.

Chen, Y. L., Palta, J., Clements, J., Buirchell, Kadambot, H. M. Siddique, Rengel, Z.: Root architecture alteration of narrow-leafed lupin and wheat in response to soil compaction, Field Crops Research, 165, pp. 61-70, https://doi.org/10.1016/j.fcr.2014.04.007, 2014.

Chopra, U. K., Sundara Sarma, K. S., Kalra, N.: Effect of mulching on soil and plant water status, and the growth and yield of wheat (Triticum aestivum L.) in a semi-arid environment, Agricultural Water Management, 95(12), pp. 1323-1334, https://doi.org/10.1016/j.agwat.2008.06.001, 2008.

Christian, D. G. and Ball, B. C.: Reduced cultivations and direct drilling for cereals in Great Britain', Conservation Tillage in Temperate Agroecosystems. Boca Raton, Florida, USA: Lewis Publishers, pp. 117-140, 1994.

Chyba, J.: The influence of traffic intensity and soil texture on soil water infiltration rate. Msc, Harper adams University, Newport, UK, 2012.

Colombi, T. and Walter, A.: Genetic Diversity under Soil Compaction in Wheat: Root Number as a Promising Trait for Early Plant Vigor', Frontiers in Plant Science, 8, pp. 420, https://doi.org/10.3389/fpls.2017.00420, 2017.

Cooper, H. V., Sjogersten, S., Lark, R. M., Mooney, S. J.: To till or not to till in a temperate ecosystem? Implications for climate change mitigation', Environmental Research Letters, 16(5), pp. 054022, 2021. 
da Silva, A. P., Kay, B. D. and Perfect, E.: Characterization of the Least Limiting Water Range of Soils, Soil Science Society of America Journal, 58(6), pp. 1775-1781, 1994.

Cranfield University.: The soil guide. Available: www.landis.org.uk. Cranfield University, UK, 2021.

Czyż, E. A.: Effects of traffic on soil aeration, bulk density and growth of spring barley', Soil and Tillage Research, 79(2), pp. 153-166, https://doi.org/10.1016/j.still.2004.07.004, 2004.

da Silva, A. P., Kay, B. D. and Perfect, E.: Characterization of the Least Limiting Water Range of Soils, Soil Science Society of America Journal, 58(6), pp. 1775-1781, 1994.

de Dorlodot, S., Forster, B., Pages, L., Price, A., Tuberosa, R., Draye, X.: Root system architecture: opportunities and constraints for genetic improvement of crops, Trends in Plant Science, 12(10), pp. 474-481, 10.1016/j.tplants.2007.08.012, 2007.

Defossez, P. and Richard, G.: Models of soil compaction due to traffic and their evaluation', Soil and Tillage Research, 67(1), pp. 41-64, doi: 10.1016/SO167-1987(02)00030-2, 2002.

Doussan, C., Pierret, A., Garrigues, E., Pages, L.: Water Uptake by Plant Roots: II - Modelling of Water Transfer in the Soil Root-system with Explicit Account of Flow within the Root System - Comparison with Experiments, Plant and Soil, 283(1), pp. 99-117, doi: https://doi.org/10.1007/s11104-004-7904-z, 2006.

Ehdaie, B., Merhaut, D. J., Ahmadian, S., Hoops, A. C., Khuong, T.: Root System Size Influences Water-Nutrient Uptake and Nitrate Leaching Potential in Wheat, Journal of Agronomy and Crop Science, 196(6), pp. 455-466, doi: 10.1111/j.1439-037X.2010.00433.x, 2010.

Ehlers, W. and Claupein, W.: Approaches Towards Conservation Tillage in Germany, Conservation Tilage in Temperate Agroecosystems, 1st Edition edn., CRC Press, p. 25, 1994.

FAO World Food Situation, May 2018 | World Food Situation | Food and Agriculture Organization of the United Nations (fao.org), 2018.

Flavel, R. J., Guppy, C. N., Rabbi, S. M. R., Young, I. M.: An image processing and analysis tool for identifying and analysing complex plant root systems in 3D soil using non-destructive analysis: Root1, PloS one, 12(5), pp. e0176433-e0176433, doi: https://doi.org/10.1371/journal.pone.0176433, 2017.

Foley, J. A., Ramankutty, N., Brauman, K. A., Cassidy, E. S., Gerber, J. S., Johnston, M., Mueller, N. D., O'Connell, C., Ray, D. K., West, P. C., Balzer, C., Bennett, E. M., Carpenter, S. R., Hill, J., Monfreda, C., Polasky, S., Rockstrom, J., Sheehan, J., Siebert, S., Tilman, D., Zaks, D. P. M.: Solutions for a cultivated planet, Nature, 478(7369), pp. 337-342, 2011

Gee, G. W. and Or, D.: Particle-Size Analysis, Methods of Soil Analysis: Part 4 Physical Methods, 5.4, Dane, J. H., Topp, G. C., pp. 255-293, doi: https://doi.org/10.2136/sssabookser5.4.c12, 2002.

Gregory, P. J., McGowan, M., Biscoe, P. V., Hunter, B.: Water relations of winter wheat: 1. Growth of the root system, The Journal of Agricultural Science, 91(1), pp. 91-102, doi: https://doi.org/10.1017/S0021859600056653, 1978.

Grzesiak, M. T., Ostrowska, A., Hura, K., Rut, G., Janowiak, F., Rzepka, A., Hura, T., Grzesiak, S.: Interspecific differences in root architecture among maize and triticale genotypes grown under drought, waterlogging and soil compaction.', Acta Physiol plant, 36, 2014 
Guan, D., Yushi, Z., Al-Kaisi, M., Mahdi, M., Qingyan, W., Mingcai, Z., Zhaohu, L.: Tillage practices effect on root distribution and water use efficiency of winter wheat under rain-fed condition in the North China Plain, Soil and Tillage Research, 146, pp. 286-295, doi: 10.1016/j.still.2014.09.016, 2015.

Guo, X., Svane, S. F., Füchtbauer, W. S., Andersen, J. R., Jensen, J., Thorup-Kristensen, K.: Genomic prediction of yield and root development in wheat under changing water availability', Plant Methods, 16(1), pp. 90, 2020.

Hamblin, A. P. and Tennant, D.: Root length density and water uptake in cereals and grain legumes: how well are they correlated', Australian Journal of Agricultural Research, 38(3), pp. 513-527, doi: 10.1071/AR9870513, 1987.

Hamza, M. A. and Anderson, W. K.: Soil compaction in cropping systems: A review of the nature, causes and possible solutions', Soil and Tillage Research, 82(2), pp. 121-145, doi: https://doi.org/10.1016/j.still.2004.08.009, 2005.

Houšková, B and Montanarella, L.: The natural susceptibility of European soils to compaction ', in Gergely Tóth, Luca, Montanarella \& Rusco, E. (eds.) Threats to Soil Quality in Europe. Office for Official Publications of the European Communities, Luxmbourg, 2008.

Ishaq, M., Hassan, A., Saeed, M., Ibrahim, M., Lal, R.: Subsoil compaction effects on crops in Punjab, Pakistan: I. Soil physical properties and crop yield', Soil and Tillage Research, 59(1), pp. 57-65, doi: 10.1016/S01671987(00)00189-6, 2001.

Javaux, M., Couvreur, V., Vanderborght, J., Vereecken, H.: Root Water Uptake: From Three-Dimensional Biophysical Processes to Macroscopic Modeling Approaches', Vadose Zone Journal, 12(4), https://doi.org/10.2136/vzj2013.02.0042, 2013.

Kaczorowska-Dolowy, M., Godwin, R. J., Dickin, E., White, D. R., Misiewicz, P. A.: Controlled traffic farming delivers better crop yield of winter bean as a result of improved root development, Agronomy Research, 17(3), doi: https://doi.org/10.15159/ar.19.136, 2019.

Lal, R.: Agricultural activities and the global carbon cycle', Nutrient Cycling in Agroecosystems, 70(2), pp. 103116,2004

Lal, R.: Beyond Copenhagen: mitigating climate change and achieving food security through soil carbon sequestration', Food Security, 2(2), pp. 169-177, 2010.

Lapen, D. R., Topp, G. C., Gregorich, E. G., Curnoe, W. E.: Least limiting water range indicators of soil quality and corn production, eastern Ontario, Canada', Soil and Tillage Research, 78(2), pp. 151-170, doi: 10.1016/j.still.2004.02.004, 2004.

Lipiec, J., Horn, R., Pietrusiewicz, J., Siczek, A.: Effects of soil compaction on root elongation and anatomy of different cereal plant species, Soil and Tillage Research, 121, pp. 74-81, doi: 10.1016/j.still.2012.01.013, 2012. Lynch, J. P. and Brown, K. M.: Topsoil foraging - an architectural adaptation of plants to low phosphorus availability, Plant and Soil, 237(2), pp. 225-237, 2001.

Mangalassery, S., Sjogersten, S., Sparkes, D. L., Sturrock, C. J., Craigon, J., Mooney, S. J.: To what extent can zero tillage lead to a reduction in greenhouse gas emissions from temperate soils?, Scientific Reports, 4(1), pp. 4586, 2014.

Millington, W. A., Misiewicz, P., White, D., Dickin, E., Mooney, S. J., Godwin, R. J.: An investigation into the effect of traffic and tillage on soil properties using X-ray computed tomography', 2017 ASABE Annual International Meeting, pp. 1, doi: 10.13031/aim.201700380, 2017. 
Mooney, S. J., Pridmore, T. P., Helliwell, J., Bennett, M. J.: Developing X-ray Computed Tomography to noninvasively image 3-D root systems architecture in soil', Plant and Soil, 352(1), pp. 1-22, 2012.

Morris, E. C., Griffiths, M., Golebiowska, A., Mairhofer, S., Burr-Hersey, J., Goh, T., von Wangenheim, D., Atkinson, B., Sturrock, C. J., Lynch, J. P., Vissenberg, K., Ritz, K., Wells, D. M., Mooney, S. J., Bennett, M. J.: Shaping 3D Root System Architecture', Current Biology, 27(17), pp. R919-R930, doi:10.1016/j.cub2017.06.043, 2017.

Morris, N. L., Miller, P. C. H., Orson, J. H., Froud-Williams, R. J.: The adoption of non-inversion tillage systems in the United Kingdom and the agronomic impact on soil, crops and the environment-A review, Soil and Tillage Research, 108(1), pp. 1-15, 2010.

Muñoz-Romero, V., Benitez-Vega, J., Lopez-Bellido, R. J., Fontan, J. M., Lopez-Bellido, L.: Effect of tillage system on the root growth of spring wheat, Plant and Soil, 326(1), pp. 97-107, 2010.

Naderi-Boldaji, M., Kazemzadeh, A., Hemmat, A., Rostami, S., Keller, T.: Changes in soil stress during repeated wheeling: A comparison of measured and simulated values', Soil Research, 56(2), pp. 204-214, doi: 10.1071/SR17093, 2017.

Otto, R., Silva, A. P., Franco, H. C. J., Oliveira, E. C. A., Trivelin, P. C. O.: High soil penetration resistance reduces sugarcane root system development, Soil and Tillage Research, 117, pp. 201-210, doi: 10.1016/j.still.2011.10.005, 2011.

Pfeifer, J., Kirchgessner, N., Colombi, T., Walter, A.: Rapid phenotyping of crop root systems in undisturbed field soils using X-ray computed tomography, Plant Methods, 11(1), pp. 41, 2015.

Pires, L. F., Borges, J. A. R., Rosa, J. A., Cooper, M., Heck, R. J., Passoni, S., Roque, W.L.: Soil structure changes induced by tillage systems', Soil and Tillage Research, 165, pp. 66-79, https://doi.org/10.1016/j.still.2016.07.010, 2017.

Rab, M. A., Haling, R., Aarons, S., Hannah, M., Young, I., Gibson, D.: Evaluation of X-ray computed tomography for quantifying macroporosity of loamy pasture soils', Geoderma, 213, pp. 460-470, doi: 10.1016/J.GEODERMA.2013.08.037, 2014.

Raper, R. L.: Agricultural traffic impacts on soil', Journal of Terramechanics, 42(3), pp. 259-280, https://doi.org/10.1016/j.jterra.2004.10.010, 2005.

Reicosky, D. C., Reeves, D. W., Prior, S. A., Runion, G. B., Rogers, H., Raper, R. L.: Effects of residue management and controlled traffic on carbon dioxide and water loss, Soil and Tillage Research, 52(3), pp. 153165, doi: 10.1016/S0167-1987(99)00065-3, 1999.

Ren, L., Vanden Nest, T., Ruysschaert, G., D'Hose, T., Cornelis, W. M.: Short-term effects of cover crops and tillage methods on soil physical properties and maize growth in a sandy loam soil', Soil and Tillage Research, 192, pp. 76-86, https://doi.org/10.1016/j.still.2019.04.026, 2019.

Romaneckas, K., Romaneckien, R., Sarauskis, E., Pilipaviius, V.: The effect of conservation primary and zero tillage on soil bulk density, water content, sugar beet growth and weed infestation, Agronomy Research, 7(1), pp. 73-86, 2009

Six, J., Ogle, S. M., Breidt, F. J., Conant, R. T., Mosier, A. R., Paustian, K.: The potential to mitigate global warming with no-tillage management is only realized when practised in the long term', Global Change Biology, 10(2), pp. 155-160, https://doi.org/10.1111/j.1529-8817.2003.00730.x, 2004. 
922
Skaalsveen, K., Ingram, J. and Clarke, L. E. : The effect of no-till farming on the soil functions of water purification and retention in north-western Europe: a literature review, Soil \& Tillage research, 189, pp. 98-109, doi:10.1016/j.still.2019.01.004, 2019.

Smith, E. The effect of agricultural traffic and tillage on soil physical properties and crop yields: A thesis submitted in partial fulfilment of the requirements for the degree of Doctor of Philosophy. Newport: Harper Adams University. PhD, Harper Adams University, Newport, 2016.

Soane, B. D., Blackwell, B. D., Dickson, J. W., Painter, D. J.: Compaction by agricultural vehicles: A review II. Compaction under tyres and other running gear', Soil and Tillage Research, 1, pp. 373-400, https://doi.org/10.1016/0167-1987(80)90039-2, 1980.

Soane, G. C., Godwin, R. J. and Spoor, G.: Influence of deep loosening techniques and subsequent wheel traffic on soil structure', Soil and Tillage Research, 8, pp. 231-237, doi: 10.1016/0167-1987(86)90336-3, 1986.

Stewart, C. E., Halvorson, A. D. and Delgado, J. A.: Long-term N fertilization and conservation tillage practices conserve surface but not profile SOC stocks under semi-arid irrigated corn, Soil and Tillage Research, 171, pp. 9$18,2017$.

Soane, B. D., Ball, B. C., Arvidsson, J., Basch, G., Moreno, F., Roger-Estrade, J.: No-till in northern, western and south-western Europe: A review of problems and opportunities for crop production and the environment, Soil and Tillage Research, 118, pp. 66-87, doi: 10.1016/j.still.2011.10.015, 2012.

Stroud, J. L., Irons, D. E., Watts, C. W., Storkey, J., Morris, N. L., Stobart, R. M., Fielding, H. A., Whitmore, A. P.: Cover cropping with oilseed radish (Raphanus sativus) alone does not enhance deep burrowing earthworm (Lumbricus terrestris) midden counts', Soil and Tillage Research, 165, pp. 11-15, https://doi.org/10.1016/j.still.2016.07.013, 2017.

Tinker, P. B. and Nye, P. H.: Solute movement in the Rhizosphere'. Oxford: Oxford University press, 2000.

Tormena, C. A., da Silva, A. P. and Libardi, P. L.: Soil physical quality of a Brazilian Oxisol under two tillage systems using the least limiting water range approach, Soil and Tillage Research, 52(3), pp. 223-232, doi: 10.1016/S0167-1987(99)00086-0, 1999.

Tracy, S. R., Black, C. R., Roberts, J. A., McNeill, A., Davidson, R., Tester, M., Samec, M., Korosak, D., Sturrock, C., Mooney, S. J.: Quantifying the effect of soil compaction on three varieties of wheat (Triticum aestivum L.) using X-ray Micro Computed Tomography (CT), Plant and Soil, 353(1), pp. 195-208, 2012.

Tracy, S. R., Black, C. R., Roberts, A., Mooney, S. J.: Exploring the interacting effect of soil texture and bulk density on root system development in tomato (Solanum lycopersicum L.)', Environmental and Experimental Botany, 91, pp. 38-47, doi: 10.1016/j.envexpbot.2013.03.003, 2013.

Wang, M.-B. and Zhang, Q.: Issues in using the WinRHIZO system to determine physical characteristics of plant fine roots, Acta Ecologica Sinica, 29(2), pp. 136-138, doi:10.1016/j.chnaes.2009.05.007, 2009.

Whalley, W. R., Watts, C. W., Gregory, A. S., Mooney, S. J., Clark, L. J., Whitmore, A. P.: The effect of soil strength on the yield of wheat', Plant and Soil, 306(1), pp. 237, 2008.

White, C. A., Sylvester-Bradley, R. and Berry, P. M. Root length densities of UK wheat and oilseed rape crops with implications for water capture and yield', Journal of Experimental Botany, 66(8), pp. 2293-2303, https://doi.org/10.1093/jxb/erv077, 2015. 
https://doi.org/10.5194/soil-2021-129

Preprint. Discussion started: 30 November 2021

(c) Author(s) 2021. CC BY 4.0 License.

974

978

979

980

981

982

983

984
Wildenschild, D., Vaz, C. M. P., Rivers, M. L., Rikard, D., Christensen, B. S. B.: Using X-ray computed tomography in hydrology: systems, resolutions, and limitations, Journal of Hydrology, 267(3), pp. 285-297, doi:10.1016/S0022-1694(02)00157-9, 2002.

Zadoks, J. C., Chang, T. T. and Konzak, C. F.: A decimal code for the growth stages of cereals, Weed Research, 14(6), pp. 415-421, doi:10.1111/j.1365-3180.1974.tb01084.x, 1974.

Zhou, H., Whalley, W. R., Hawkesford, M. J., Ashton, R. W., Atkinson, B., Atkinson, J. A., Sturrock, C. J., Bennett, M. J., Mooney, S. J.: The interaction between wheat roots and soil pores in structured field soil, Journal of Experimental Botany, 72(2), pp. 747-756, https://doi.org/10.1093/jxb/eraa475, 2021. 